\title{
Interannual persistence of the seasonal snow cover in a glacierized catchment
}

\author{
Kay HELFRICHT, ${ }^{1,2}$ Johannes SCHÖBER, ${ }^{3}$ Katrin SCHNEIDER, ${ }^{1}$ Rudolf SAILER, ${ }^{1,4}$ \\ Michael KUHN² \\ ${ }^{1}$ alpS - Centre for Climate Change Adaptation, Innsbruck, Austria \\ E-mail: kay.helfricht@oeaw.ac.at \\ ${ }^{2}$ Institute of Meteorology and Geophysics, University of Innsbruck, Austria \\ ${ }^{3}$ TIWAG Tiroler Wasserkraft AG, Innsbruck, Austria \\ ${ }^{4}$ Institute of Geography, University of Innsbruck, Austria
}

\begin{abstract}
Knowledge of the spatial snow distribution and its interannual persistence is of interest for a broad spectrum of issues in cryospheric sciences. In this study, snow depths derived from airborne laser scanning are analyzed for interannual persistence of the seasonal snow cover in a partly glacierized mountain area $\left(\sim 36 \mathrm{~km}^{2}\right)$. At the end of five accumulation periods, the snow-covered area varied by $16 \%$ of its temporal mean. Mean snow depth of the total area ranged by a factor of two (1.31$2.58 \mathrm{~m}$ ), with a standard deviation of $0.42 \mathrm{~m}$. Interannual correlation coefficients of snow depth distribution were in the range $0.68-0.84$. Of the investigated area, $75 \%$ was found to be interannually persistent. The remaining area showed variable snow cover from year to year, caused by occasional avalanches and changes in surface topography as a result of glacier retreat. Snow cover underwent a change from a homogeneous distribution on the former glacier surface to a more heterogeneous snow cover in the recently deglaciated terrain. A geostatistical analysis shows interannual persistence in scaling behavior of snow depth in ice-free terrain with scale break distances at $20 \mathrm{~m}$. Scale-invariant behavior of snow depth is indicated over $>100 \mathrm{~m}$ on smooth glacier surfaces.
\end{abstract}

KEYWORDS: accumulation, mountain glaciers, remote sensing, snow, snow/ice surface processes

\section{INTRODUCTION}

The spatial distribution of mountain snow cover is of interest in cryospheric science for issues such as modelling mass balance of glaciers (e.g. Huss and others, 2008; Dadic and others, 2010a), determining the snow-cover duration for ecological investigations (e.g. Tappeiner and others, 2001), identifying risks from natural hazards (e.g. Schweizer and others, 2008) and simulating the runoff regime of mountain catchments (e.g. Lundquist and Dettinger, 2005; Schöber and others, 2010; Bavay and others, 2013). The spatial variability of snow depths is recognized as a challenging feature, especially regarding scaling issues and the simulation of the fundamental processes causing the heterogeneity of snow (e.g. Pomeroy and others, 1998; Blöschl, 1999; Deems and others, 2006, 2008; Trujillo, 2007; Grünewald and others, 2013). Since simulations of mountain hydrology require not only runoff measurements but also ground-truth data of the snow cover for validation (e.g. Blöschl and others, 1991; Huss and others, 2014), snowcover distribution is measured using in situ measurements (e.g. Elder and others, 1991; Kaser and others, 2003; Lundberg and others, 2010) and remote-sensing techniques (e.g. Nolin, 2010; Rittger and others, 2013). Point information from weather stations or snow depth measurements is used to interpolate and extrapolate the mountain snow cover to the catchment scale for snow-hydrological studies (e.g. Blöschl and others, 1991; Anderton and others, 2004). However, the representativeness of individual measurements is uncertain (Sevruk, 1986; Grünewald and Lehning, 2011). The lidar remote-sensing technique (e.g. Baltsavias, 1999; Wehr and Lohr, 1999) is a useful tool to obtain spatially distributed snow depth data at high spatial resolution from repeated surveys (Deems and others, 2013). Lidar was applied to derive snow depths in test areas (e.g. Hopkinson and others, 2001; Deems and others, 2006, 2008), on individual mountain slopes (e.g. Prokop and others, 2008; Sailer and others, 2008; Schaffhauser and others, 2008; Grünewald and others, 2010; Schirmer and others, 2011), for individual glaciers (e.g. Jörg and others, 2006; Geist and Stötter, 2007; Sold and others, 2013; Helfricht and others, 2014) and entire mountain catchments (e.g. Dadic and others, 2010a; Helfricht and others, 2012; Grünewald and others, 2013; Schöber and others, in press). However, multi-annual data of spatial snow depth distribution, i.e. the total volume of snow cover over entire catchments, are rare.

Interannual persistence of the spatial snow distribution is a prerequisite for applying simple parameterizations of snow redistribution in hydro-meteorological models simulating the snow cover of high mountain catchments (e.g. Huss and others, 2008; Strasser, 2008; Dadic and others, 2010b; Mott and others, 2010; Schöber and others, in press). Until now, long-term observations of spatially distributed snow depths have been based on manually taken snow depth samples (Sturm and Wagner, 2010; Jepsen and others, 2012; Winstral and Marks, 2014). Sturm and Wagner (2010) showed that climatological snow patterns derived from multi-annually measured snow depth distributions are suitable for simulating the snow depth distribution. In alpine mountain catchments, spatial snow distribution is attributed to preferential deposition of snow and the subsequent windinduced snow transport processes acting on various scales 
(e.g. Lehning and others, 2008; Dadic and others, 2010a; Mott and others, 2010). Mott and others (2011a) suggest that a model resolution of $5 \mathrm{~m}$ is not sufficient to capture all processes that drive snow-cover variability in areas of complex alpine topography.

Geostatistical analyses are the basis for the spatial design of measurements of snow depth and snow-cover models (Blöschl, 1999). Snow cover presents a multi-scaling behavior (e.g. Shook and Gray, 1996; Deems and others, 2008; Schirmer and Lehning, 2011) with a short-range fractal and a long-range fractal separated by a scale break. Typical scale breaks of snow depths were observed between meters and tens of meters, both for manually taken snow samples (e.g. Shook and Gray, 1996) and snow depths derived from lidar data (Deems and others, 2006, 2008; Trujillo, 2007; Schirmer and Lehning, 2011). The fractal (Hausdorff-Besicovich) dimension was found to be useful for analyzing the irregularity of objects and surfaces (Burrough, 1993; Gao and Xia, 1996). The fractal dimension allows the influence of short-range fluctuations (caused by, e.g., snow surface structures, sastrugi and cornices) to be differentiated from long-range fluctuations, related to topography, on snow-cover variability (e.g. Schirmer and Lehning, 2011). Detailed analyses of multi-annual consistency in scaling behavior based on high-resolution lidar data are limited to the comparison of two accumulation seasons. Schirmer and Lehning (2011) and Deems and others (2008) indicate an interannual consistency of fractal dimensions and scale breaks of snow depths at the end of the accumulation season. Schirmer and Lehning (2011) showed that the scale breaks increase while short-range fractal dimensions decrease, due to smoothing of the surface by snow accumulation associated with northwesterly storms towards the end of the accumulation season.

In this study, a unique multi-year dataset of snow depths is introduced, derived from airborne laser scanning (ALS) surveys of the seasonal snow cover in a partly glacierized mountain catchment of $\sim 36 \mathrm{~km}^{2}$. The detailed snow depth data allow the combination of the advantages of high spatial resolution and multi-annual data. The study aims to investigate the temporal and spatial interannual persistence of seasonal snow depths, snow patterns and scaling behavior of the snow cover.

Annual mean snow depths and their spatial variability are determined, to compare the overall temporal persistence of snow accumulation in the investigated basin. Correlation coefficients between each of the annual snow depth distributions are calculated at spatial resolutions of 1-100 $\mathrm{m}$. This allows us to differentiate between processes causing high interannual variability, even at coarser resolutions; and the increasing correlation with decreasing resolution as a result of a reduction of the spatial variability of snow depth (e.g. Blöschl, 1999; Melvold and Skaugen, 2013). Areas with persistent snow cover are distinguished from areas with variable snow cover by analyzing the temporal variability in standardized snow depths. Maps of squared errors of standardized snow depths are shown to locate processes causing interannual differences in snow patterns. A $k$-means clustering is used to detect areas of similar spatial and temporal characteristics of the residuals of snow depths from the mean snow depth in their vicinity. Finally, the interannual variability in fractal dimensions and scale breaks of the snow depth distribution is derived from a semivariance analysis.
The results help emphasize the main characteristics of the snow depth distribution in this Alpine catchment and support simulations of the snow cover in this mountain region and comparable mountain basins.

\section{STUDY SITE AND DATA}

The investigated area is located on the main Alpine ridge in the Ötztal Alps, Austria $\left(46^{\circ} 48^{\prime} \mathrm{N}, 10^{\circ} 46^{\prime} \mathrm{E}\right)$. It covers a partly glacierized catchment of the upper Rofen valley (Fig. 1). The total area is $35.9 \mathrm{~km}^{2}$, of which $50 \%$ was glacierized in 2001 and 44\% in 2011; i.e. a loss in glacier area of $12 \%$ in 10 years. The elevation within the study area ranges from 2234 to $3738 \mathrm{~m}$ a.s.l. The mean elevation over the investigated area is $3005 \mathrm{ma.s.l}$. Aspect is predominantly southeast at elevations below $2500 \mathrm{~m}$ a.s.l. (Fig. 1). Most slopes face southeast and northwest at elevations between 2500 and 3500 ma.s.l. Aspects from southwest to west are, in general, less frequent. Most of the area below $3000 \mathrm{~m}$ a.s.l. has a slope angle of $20-40^{\circ}$. Between 3000 and $3500 \mathrm{~m}$ a.s.l., glacier surfaces with a slope of $<30^{\circ}$ are most frequent. The glaciers Hintereisferner (HEF) and Kesselwandferner (KWF) are located in the investigated area. Both glaciers have been monitored for decades (Hoinkes, 1970; Kuhn and others, 1999; Fischer, 2010; Fischer and others, 2012). The upper parts of the glaciers Gepatschferner (GPF) and Langtauferer Ferner (LF) are partly included in the investigated area. Since 2001, annual ALS flights have been conducted in this mountain area, from which annual glacier volume changes (Geist and others, 2005; Bollmann, 2010) and intra-annual surface elevation changes (Geist and Stötter, 2007) have been calculated. For this study, glacier outlines were derived separately for the date of ALS( $t 1)$ according to Abermann and others (2010). Available ALS data cover five accumulation seasons between 2001 and 2012 .

Table 1 shows the dates of the ALS surveys, along with the devices used, maximum scan angles, laser repetition rates, scan frequencies and assessments of the vertical accuracy since 2002. Vertical accuracy was derived by comparing ALS data with a flat and snow-free reference surface down the valley near the study area. Mean deviation between actual altitude of the reference surface and the $z$-value of the lidar points had a maximum of $0.076 \mathrm{~m}$ and a maximum standard deviation of $0.11 \mathrm{~m}$ (Table 1). Point densities increase over time due to the improvement in scanner devices. Mean flight speed was $65-70 \mathrm{~m} \mathrm{~s}^{-1}$. Mean flight altitude was 1000-1200 m above ground.

Point clouds were filtered to bare ground using last returns of the laser signal. All points within a gridcell were averaged to generate digital elevation models (DEMs) with a grid size of $1 \mathrm{~m}$. Gridcells without lidar point measurements were filled using inverse distance weighting. Due to the high number of measured points and the location of the investigation area above the tree line, simple interpolation schemes deliver high-accuracy DEMs (Deems and others, 2013). Bollmann and others (2011) estimated that DEMs produced in the Hintereisferner region had a relative vertical accuracy better than $\pm 0.15 \mathrm{~m}$ for slopes less than $35^{\circ}$. The accuracy of the ALS measurements decreases considerably with increasing laser distance and decreasing illumination angle (Bollmann and others, 2011; Joerg and others, 2012). Early-stage application of ALS measurements in 2002 might be influenced by higher uncertainties due to the lower point 

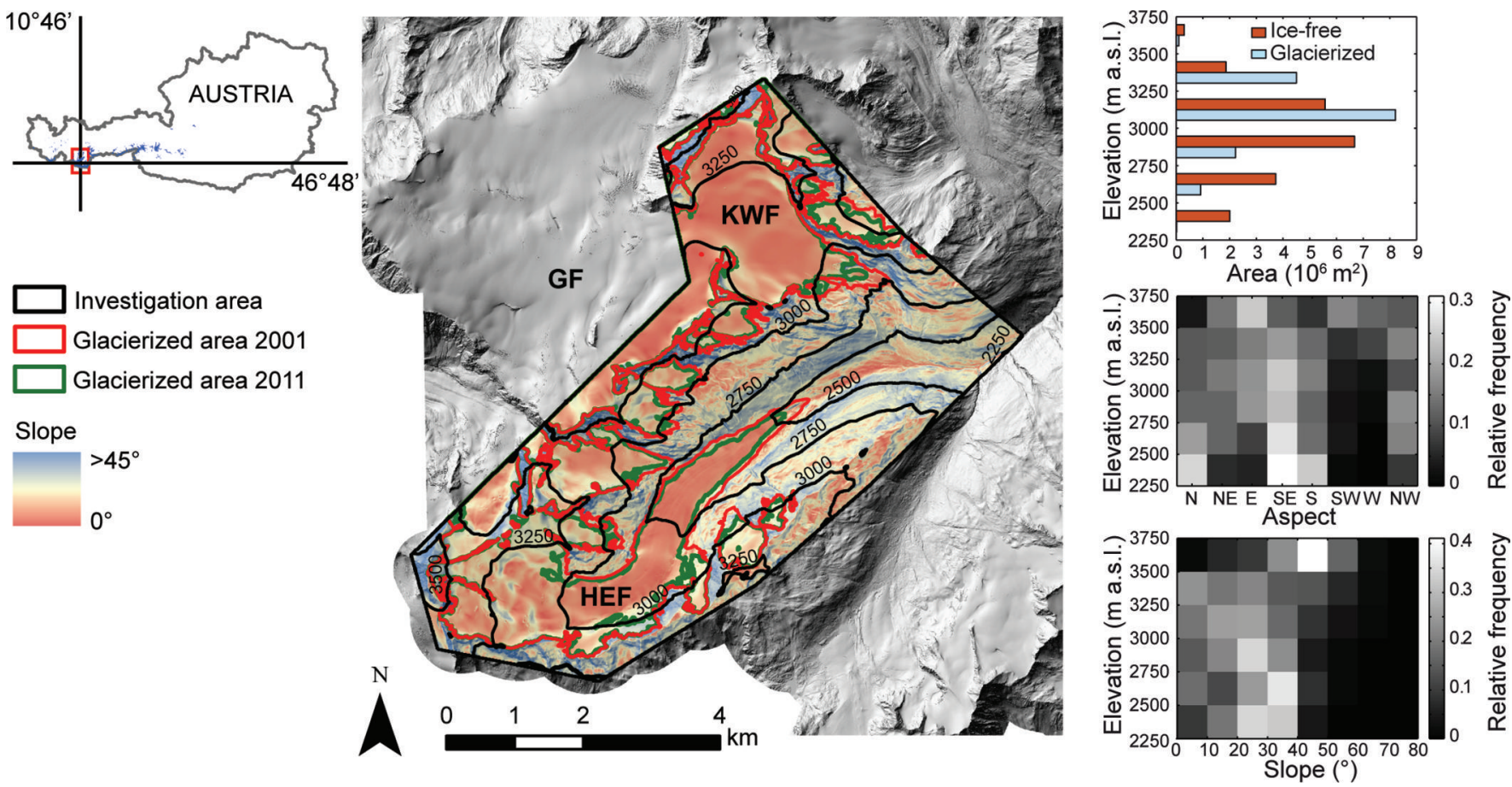

Fig. 1. Map of the investigated area, including the glaciers Hintereisferner (HEF), Kesselwandferner (KWF) and the uppermost part of Gepatschferner (GF). The color scale shows the slope of the surface. Glacier outlines for the years 2001 (red) and 2011 (green) and contour lines of elevation in $250 \mathrm{~m}$ steps (black) are presented. The area/elevation distribution (upper right) and the frequency distribution of aspect (middle right) and slope (lower right) of $250 \mathrm{~m}$ elevation zones are shown.

densities compared with the subsequent years (Bollmann and others, 2011; Fritzmann and others, 2011).

Two lidar surveys are required to extract seasonal snow depth from multi-temporal ALS data (e.g. Hopkinson and others, 2001; Deems and others, 2013). Data have to be recorded prior to the accumulation season ('snow-off', here referred to as date 11 ) and at the time of maximum snow depth ('snow-on', here referred to as date $t 2$; Table 1). In mountain catchments with a high elevation range it is difficult to cover the date of the minimum and maximum accumulation exactly. While snow accumulates at higher elevations, ice- and snowmelt can simultaneously occur at lower elevations.
The densification of fresh snow accumulated prior to ALS (t1) causes underestimation of snow depths by lidar measurements. Snow ablation or ice ablation lowers the surface between $A L S(t 1)$ and the final formation of the seasonal snow cover and thus can also lead to underestimation of the snow depths. The densification of the firn cover and ice flow causes underestimation of the snow depths by lidar in typical accumulation areas of the glaciers (e.g. Sold and others, 2013; Helfricht and others, 2014). With respect to the glacierized study area, the dates of the ALS flights (Table 1) were chosen to be close to the typical dates of glacier mass-balance measurements using the fixed date system (e.g. Kaser and others, 2003).

Table 1. Overview of the ALS flight campaigns investigated in this study. The accuracy is obtained from deviations between ALS surface elevations and elevations of a known reference surface. Mean flight altitude was 1000-1200 m above ground

\begin{tabular}{|c|c|c|c|c|c|c|c|c|c|c|}
\hline \multirow{3}{*}{$\begin{array}{l}\text { Accumulation } \\
\text { season }\end{array}$} & \multirow{3}{*}{$\begin{array}{l}\text { Time } \\
\text { stamp }\end{array}$} & \multirow[t]{3}{*}{ Date } & \multirow[t]{3}{*}{ Laser system } & \multirow{3}{*}{$\begin{array}{c}\text { Maximum } \\
\text { scan angle } \\
\text { 。 }\end{array}$} & \multirow{3}{*}{$\begin{array}{l}\text { Laser } \\
\text { epetition rate } \\
10^{3} \mathrm{~s}^{-1}\end{array}$} & \multirow{3}{*}{$\begin{array}{c}\text { Scan } \\
\text { frequency } \\
\mathrm{s}^{-1}\end{array}$} & \multirow{3}{*}{$\begin{array}{c}\text { Beam } \\
\text { divergence } \\
\text { mrad }\end{array}$} & \multirow{3}{*}{$\begin{array}{c}\text { Mean point } \\
\text { density } \\
\mathrm{m}^{-2}\end{array}$} & \multicolumn{2}{|c|}{ Vertical accuracy } \\
\hline & & & & & & & & & Mean & $\sigma$ \\
\hline & & & & & & & & & $\mathrm{m}$ & $\mathrm{m}$ \\
\hline \multirow[t]{2}{*}{2002} & $\mathrm{t} 1$ & 10 October 2001 & Optech ALTM 1225 & 20 & 25 & 28 & 0.1 & 1.1 & na & na \\
\hline & $\mathrm{t} 2$ & 07 May 2002 & Optech ALTM 1225 & 20 & 25 & 28 & 0.1 & 1.2 & -0.040 & 0.110 \\
\hline \multirow[t]{2}{*}{2003} & $\mathrm{t} 1$ & 18 September 2002 & Optech ALTM 2050 & 20 & 50 & 40 & 0.2 & 1.0 & -0.030 & 0.098 \\
\hline & t2 & 04 May 2003 & Optech ALTM 2050 & 20 & 50 & 40 & 0.2 & 0.8 & -0.020 & 0.092 \\
\hline \multirow[t]{2}{*}{2009} & $\mathrm{t} 1$ & 09 September 2008 & Optech ALTM 3100 & 20 & 70 & 40 & 0.3 & 2.2 & 0.002 & 0.057 \\
\hline & $\mathrm{t} 2$ & 07 May 2009 & Optech ALTM 3100 & 20 & 70 & 38 & 0.3 & 2.4 & 0.040 & 0.054 \\
\hline \multirow[t]{2}{*}{2011} & $\mathrm{t} 1$ & 08 October 2010 & Optech ALTM Gemini & 25 & 70 & 36 & 0.25 & 3.6 & 0.076 & 0.047 \\
\hline & t2 & 20 April 2011 & Optech ALTM Gemini & 25 & 70 & 36 & 0.25 & 3.8 & -0.007 & 0.041 \\
\hline \multirow[t]{2}{*}{2012} & $\mathrm{t} 1$ & 04 October 2011 & Optech ALTM 3100 & 20 & 70 & 40 & 0.3 & 2.9 & 0.001 & 0.042 \\
\hline & $\mathrm{t} 2$ & 11 May 2012 & Optech ALTM 3100 & 20 & 70 & 40 & 0.3 & 2.8 & 0.005 & 0.057 \\
\hline
\end{tabular}



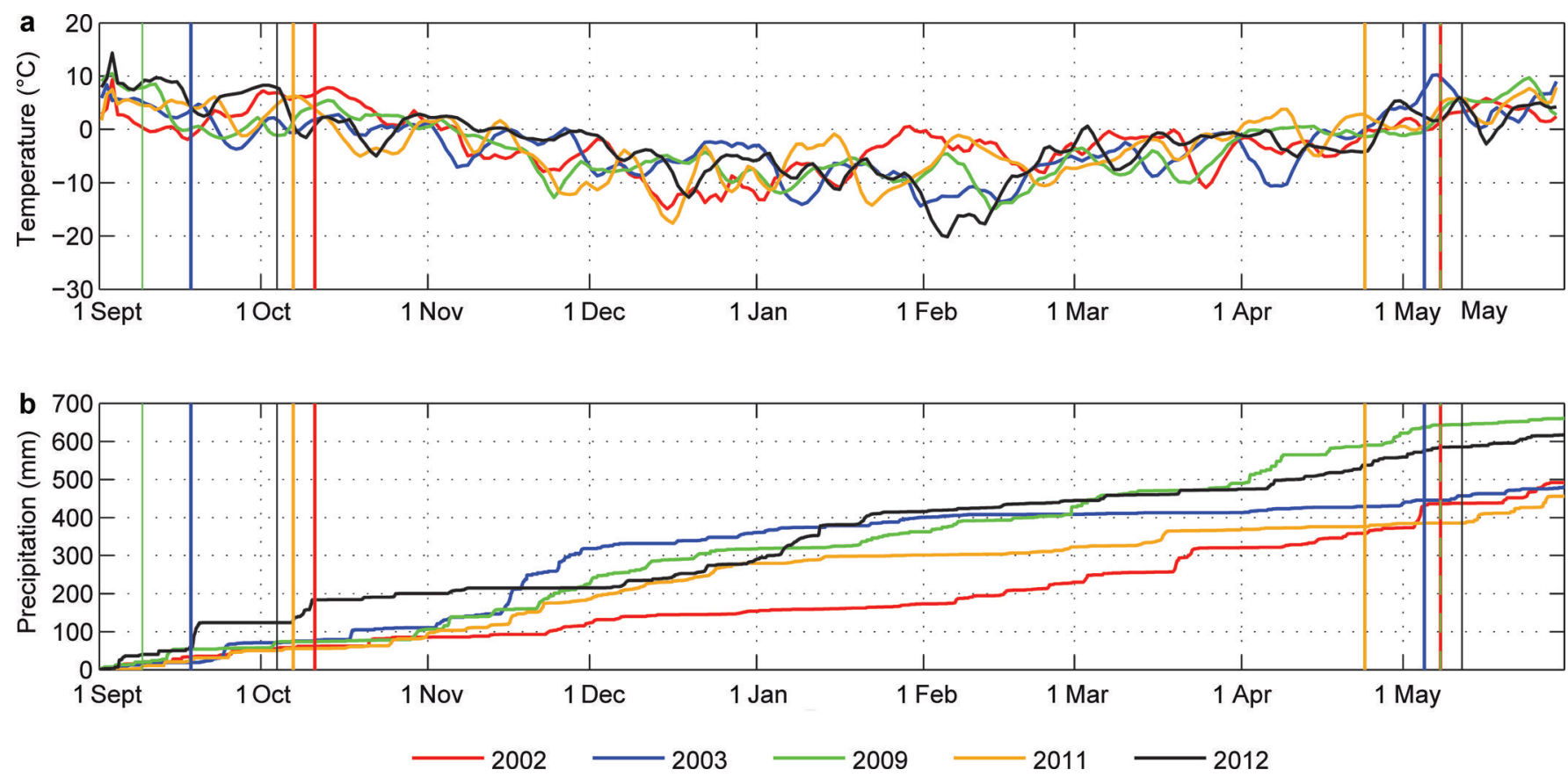

Fig. 2. Mean daily air temperatures valid for an elevation of $2400 \mathrm{~m}$ a.s.l. (a) and the cumulative precipitation (b) of the five accumulation seasons. Dates of the ALS surveys are shown as vertical lines. Note that $t 2$ of 2002 and 2009 coincide on 7 May.

\section{METEOROLOGICAL CONDITIONS}

Meteorological measurements located in the investigation area do not cover the whole period of this study. To give an overview of the weather conditions, temperature and precipitation measured at six weather stations next to the investigated basin are spatially interpolated using an inverse distance weighting algorithm for precipitation and a regression approach for temperature, implemented in the preprocessing module of the flood-forecasting system of the river Inn (Achleitner and others, 2012). The data are valid for an elevation of 2400 ma.s.l., which coincides with the lowest elevations of the investigated basin (Fig. 1). Mean daily temperatures and cumulative precipitation of all five accumulation seasons are shown in Figure 2.

In September 2001, a snow cover was accumulated in the study area and persisted until $\mathrm{ALS}(t 1)$ (e.g. Bollmann and others, 2011). The mean temperatures after ALS( $t 1)$ provided melt conditions from the end of September to midOctober. Only $30 \%$ of the seasonal precipitation had accumulated by the end of January. Snow accumulated frequently in February and March 2002. A precipitation event caused a distinct increase in snow depth a few days prior to $\mathrm{ALS}(t 2)$ in 2002.

In 2002, $\operatorname{ALS}(t 1)$ was performed in mid-September. Temperatures decreased to $0^{\circ} \mathrm{C}$ shortly thereafter, indicating less melting of the ice or snow until the formation of the seasonal snow cover. While $\sim 50 \%$ of the seasonal precipitation was accumulated in November, particularly the second half of this accumulation season continued with precipitation below average.

In 2008, mean daily temperatures were $\sim 0^{\circ} \mathrm{C}$ after ALS $(t 1)$. In October 2008, a period of positive temperatures caused potential melt at the glacier tongues (Schöber and others, in press). However, the highest cumulative precipitation during the five investigated accumulation seasons was measured in 2009, due to a steady occurrence of precipitation events in the second half of the accumulation season.
Snow accumulated prior to ALS( $t 1$ ) in 2010 (Helfricht and others, 2014; Schöber and others, in press). Until late January 2011, the cumulative precipitation was similar to 2009. Subsequently the accumulation season stayed dry. Positive temperatures enabled snowmelt on several days prior to ALS(t2) in April 2011.

Prior to ALS $(t 1)$ in 2011, a snow cover was accumulated in mid-September. However, this was distinctly reduced by melt until the date of $\mathrm{ALS}(t 1)$ (personal communication from A. Fischer, 2012). A snowfall was recorded shortly after ALS $(t 1)$, followed by almost dry conditions for 2 months. Higher accumulation rates were observed in December and January 2012.

Schöber and others (in press) discussed the influence of melt and sublimation during the 2009 and 2011 winter seasons based on model simulations of the energy balance of the snow cover. Whereas melt and sublimation accumulate to $0.17 \mathrm{~m}$ of the surface elevation change between $\mathrm{ALS}(t 1)$ in 2008 and $\mathrm{ALS}(t 2)$ in 2009, the same calculations resulted in a surface lowering by only $0.04 \mathrm{~m}$ between ALS $(t 1)$ in 2010 and ALS(t2) in 2011. Results for the accumulation periods 2002 and 2003 were found to be between these values.

Precipitation measured at three cumulative precipitation gauges located in the investigated catchment, namely Hintereisferner (HEF), Rofenberg (RB) and Proviantdepot (PD), allows comparison of the variability in precipitation of the five investigated seasons with a climatic series. Precipitation measured at the gauges is summarized for OctoberApril in the period 1983-2012 (Table 2). The mean cumulative precipitation of the five investigated accumulation periods is slightly higher than mean cumulative precipitation over the 30 year period at all three gauges. The maximum winter precipitation measured in this catchment during the past 30 years (in 2009) is included in the five investigated seasons. Cumulative winter precipitation was lower than the climatic mean in the 2011 season, but within one standard deviation of the winter precipitation between 
1983 and 2012. The temporal coefficient of variation, CV, of measured winter precipitation was 0.22 for the 30 year period (Table 2).

\section{METHODS OF SNOW-COVER ANALYSIS Analysis of spatial and temporal distribution}

Seasonal snow cover is analyzed based on DEMs with a grid size of $1 \mathrm{~m}$. The surface elevation at $\operatorname{ALS}(t 1)$ is subtracted from the surface elevation at $\operatorname{ALS}(t 2)$ to calculate surface elevation change, $\Delta z_{\mathrm{ALS}}$ :

$$
\Delta z_{\mathrm{ALS}}=z_{t 2}-z_{t 1} \approx H S .
$$

Values of $\Delta z_{\text {ALS }}$ are interpreted as snow depth, $H S$. HS values in the range $-10 \mathrm{~m} \leq H S \leq 15 \mathrm{~m}$ are used for the analysis. Negative $H S$, which are an artifact of the measurement principle (Hopkinson and others, 2001), are not removed, to maintain the original distribution of the ALSderived information. The temporal variability of the mean annual snow depth, $\overline{H S}$, and its spatial variability in terms of the standard deviation, $\sigma$, and the corresponding $\mathrm{CV}$ are analyzed. A threshold $H S$ of $0.15 \mathrm{~m}$ is used to distinguish between snow-free and snow-covered areas. According to the assumed relative vertical accuracy (Bollmann and others, 2011), this threshold accounts for the distribution of zero snow depths at $\pm 0.15 \mathrm{~m}$, i.e. $H S<0.15 \mathrm{~m}$ can result from zero snow depth and DEM error. Areas of $H S<0.15 \mathrm{~m}$ are also assumed to feature a scattered snow cover. The interannual persistence of $H S$ and snow-covered area, SCA, with altitude is analyzed in $25 \mathrm{~m}$ elevation zones.

Pearson correlation coefficients, $r$, of $H S$ are calculated between each combination of the five HS distributions. HS are sampled to coarser grid sizes $(10,30,50$ and $100 \mathrm{~m})$ using the area-weighted mean of the $1 \mathrm{~m} \mathrm{HS}$ values. Variability is known to decrease with increase of spatial aggregation (e.g. Blöschl, 1999). The spatial scale of $10 \mathrm{~m}$ is chosen to reduce the noise of the original $1 \mathrm{~m}$ data without losing too much information about snow-cover variability. A spatial resolution of $30 \mathrm{~m}$ was used by Sturm and Wagner (2010) and Winstral and Marks (2014), who analyzed manually sampled snow depth data. A typical scale of $50 \mathrm{~m}$ is used for the simulation of high-mountain snow cover and mountain hydrology (e.g. Strasser, 2008; Schöber and others, in press). Spatial scales of $>100 \mathrm{~m}$ show a reduction in variability of high-resolution snow depth data (e.g. Grünewald and others, 2013) and cause a distinct loss in information on spatial snow depth patterns (e.g. Melvold and Skaugen, 2013).

Spatially distributed standardized snow depths, $H S_{\mathrm{s}}$, are calculated according to Sturm and Wagner (2010) for the interannual comparison of seasonal snow depths, using

$$
H S_{\mathrm{s}}=\frac{H S-\overline{H S}}{\sigma_{H S}},
$$

where $\sigma_{H S}$ is the annual areal standard deviation of $H S$ in one winter. Squared errors of $H S_{\mathrm{s}}\left(\mathrm{SE}_{\mathrm{s}}\right)$ are calculated for all possible combinations of two available snow depth distributions (1 and 2) using

$$
\mathrm{SE}_{\mathrm{s}}=\left(H S_{\mathrm{s} 1}-H S_{\mathrm{s} 2}\right)^{2} .
$$

The resulting maps of $\mathrm{SE}_{\mathrm{s}}$ (ten in total) are used to identify regions of high interannual snow depth variability and areas of interannually persistent $H S_{\mathrm{s}}$. Areal means of the squared
Table 2. Precipitation measured between 1 October and 30 April at the three cumulative precipitation gauges: Hintereisferner (HEF), Rofenberg (RB) and Proviantdepot (PD). Winter precipitation measured in the investigated seasons is shown for each accumulation season separately. Minimum, mean and maximum values and the temporal CV are presented for the 30 year period 1983-2012

\begin{tabular}{lccc}
\hline & HEF & RB & PD \\
& $(2970 \mathrm{~m}$ a.s.l. $)$ & $(2827$ m a.s.l. $)$ & $(2737$ m a.s.l. $)$ \\
\hline ALS & & & \\
2002 & $627 \mathrm{~mm}$ & $521 \mathrm{~mm}$ & $396 \mathrm{~mm}$ \\
2003 & $502 \mathrm{~mm}$ & $488 \mathrm{~mm}$ & $370 \mathrm{~mm}$ \\
2009 & $998 \mathrm{~mm}$ & $793 \mathrm{~mm}$ & $622 \mathrm{~mm}$ \\
2011 & $578 \mathrm{~mm}$ & $440 \mathrm{~mm}$ & $344 \mathrm{~mm}$ \\
2012 & $696 \mathrm{~mm}$ & $604 \mathrm{~mm}$ & $441 \mathrm{~mm}$ \\
$1983-2012$ & & & \\
Minimum & $329 \mathrm{~mm}$ & $302 \mathrm{~mm}$ & $217 \mathrm{~mm}$ \\
Maximum & $998 \mathrm{~mm}$ & $793 \mathrm{~mm}$ & $652 \mathrm{~mm}$ \\
Mean & $632 \mathrm{~mm}$ & $526 \mathrm{~mm}$ & $410 \mathrm{~mm}$ \\
CV & 0.22 & 0.21 & 0.22 \\
& & & \\
\hline
\end{tabular}

errors of standardized snow depths, $\mathrm{MSE}_{\mathrm{s}}$, are used as a metric of overall similarity of the snow depth distributions.

\section{Residual analysis}

Spatial snow-cover variability is expressed by residuals of $H S\left(r_{H S}\right)$ to their vicinity. We use a moving-window approach to calculate the residual of each $H S$ to the mean $H S$ of its squared vicinity of $5 \times 5$ raster cells:

$$
r_{H S(x, y)}=H S(x, y)-\frac{\sum_{i=-2}^{2} \sum_{j=-2}^{2} H S(x+i, y+j)}{n},
$$

where $n$ is the number of cells of the window and $i, j$ are the distances in the $x$ - and $y$-directions from the center. While a homogeneous snow cover is characterized by almost zero $r_{H S}$, a heterogeneous snow cover shows distinctly negative and positive values of $r_{H S}$. The magnitude of $r_{H S}$ is controlled by spatial variations in the underlying topography and variability of the snow on its surface. Values of $r_{H S}$ are calculated at a raster resolution of $10 \mathrm{~m}$ within a $50 \mathrm{~m}$ square. Thus, the residual analysis covers the scale for which snow typically shows a high spatial autocorrelation (e.g. Shook and Gray, 1996; Deems and others, 2008; Schirmer and Lehning, 2011). We use a $k$-means clustering algorithm (Forgy, 1965; MacQueen, 1967; Hartigan and Wong, 1979) integrated in SAGA (System for Automated Geoscientific Analyses) to automatically group observations with similar characteristics in magnitude and temporal variability of $r_{H S}$. A set of $\sim 36000$ spatially distributed observations of $r_{H S}$ is used. Each observation consists of a five-dimensional vector representing $r_{H S}$ values over the five years. This clustering method does not create spatially connected clusters (e.g. as image segmentation algorithms). Rather, the high number of observations distributed over the entire basin are grouped into classes. We clustered the observations to a pre-set of ten classes. Frequency distributions are calculated for the annual $r_{H S}$ of all observations grouped in each of the ten classes. The advantage of clustering the $r_{H S}$ is the spatially distributed information obtained on the temporal persistence of snow depth residuals to mean snow depth in their vicinity. 


\section{Geostatistical analysis}

Geostatistical analyses are used in cryospheric sciences for scaling issues (e.g. Shook and Gray, 1996; Blöschl, 1999), to investigate topographic and wind control on spatial snow depth distribution and to analyze regional and temporal variability of fractal dimensions and typical scale breaks of mountain snow cover (e.g. Deems and others, 2006, 2008; Trujillo, 2007; Lehning and others, 2011; Mott and others, 2011a; Schirmer and Lehning, 2011).

Experimental variograms are used to analyze the spatial autocorrelation of data pairs as a function of their separation distance $h$ (Olea, 1999; Sun and others, 2006). The semivariance, $\gamma\left(h_{k}\right)$, of $H S$ is given for the mean lag distance $h$ of bin $k$ as

$$
\gamma\left(h_{k}\right)=\frac{1}{2 n_{k}} \sum_{i=1}^{n_{k}}\left(H S_{i}-H S_{i+h}\right)^{2},
$$

where $H S$ are snow depths at locations $i$ and $i+h$, and $n_{k}$ is the number of data pairs in bin $k$. The spatial characteristics of $H S$ can be explored by the properties of the variogram, i.e. nugget, sill and range (Olea, 1999). The nugget indicates small-scale variability that has not been captured by the measurement. The sill is the overall variability, $\gamma\left(h_{k}\right)$, in the dataset, i.e. the higher the sill, the higher the spatial variability in the data. The distance between sampling points (range) where the increase in $\gamma\left(h_{k}\right)$ with increasing $h$ changes considerably is called the scale break distance, $L$. In the case of flattening of the increase in $\gamma\left(h_{k}\right)$ on a log-log plot, $L$ marks the separation of the sampling points at which there is no further autocorrelation between data pairs.

The fractal (Hausdorff-Besicovich) dimension $D$ was found to be useful to analyze the irregularity of objects and surfaces (Burrough, 1993; Gao and Xia, 1996). Nearly planar surface features have $D=2$, while a rugged surface has a limiting $D=3$.

Fractal dimensions are estimated from the slope of a power law fitted to the log-spaced data

$$
\gamma\left(h_{k}\right)=\alpha \cdot h_{k^{\prime}}^{\beta}
$$

where $\alpha$ is the ordinal intercept and the power $\beta$ is the slope of the linear fit in the log-transformed variogram. The fractal dimension $D$ is calculated from $\beta$ (Gao and Xia, 1996):

$$
D=3-\frac{\beta}{2} \text {. }
$$

The application and interpretation of geostatistics is strongly limited by the measurement scale and the sampling design. For example, if the spacing between the sampling points is large compared with the extent of the sampled area, the true variability in the data might not be captured. The high spatial resolution of the ALS data supports the applicability of the semivariance analysis. However, the results of $L$ and $D$ are highly influenced by the methods used. Sources of different estimates for scale breaks and fractal dimensions are discussed by $\mathrm{Xu}$ and others (1993) and Sun and others (2006).

For this study, semivariance is calculated for HS over the entire ice-free terrain with respect to the largest glacier extent in $2001\left(17.75 \mathrm{~km}^{2}\right)$, separately for HS on Hintereisferner (HEF; $6.99 \mathrm{~km}^{2}$ ) and on Kesselwandferner (KWF; $3.65 \mathrm{~km}^{2}$ ) and for $H S$ on the remaining small glaciers $\left(2.00 \mathrm{~km}^{2}\right)$. With respect to the results of other studies analyzing geostatistical properties of Alpine HS (e.g. Deems and others, 2008; Mott and others, 2011b; Schirmer and
Table 3. Mean snow depth, $\overline{H S}$, the standard deviation of spatially distributed snow depth, $\sigma_{H S}$, the corresponding spatial CV and the snow-covered area, SCA, for each accumulation season calculated from $1 \mathrm{~m}$ gridded snow depth data. The interannual mean and interannual variability in terms of range, $\sigma$ and temporal $\mathrm{CV}$ are also shown

\begin{tabular}{lcccc}
\hline Season & $\overline{H S}$ & $\begin{array}{c}\sigma_{H S} \\
\mathrm{~m}\end{array}$ & $\mathrm{CV}$ & $\begin{array}{c}\text { SCA } \\
10^{6} \mathrm{~m}^{2}\end{array}$ \\
& $\mathrm{~m}$ & & & \\
\hline 2002 & 1.98 & 1.34 & 0.68 & 32.9 \\
2003 & 1.86 & 1.33 & 0.71 & 31.3 \\
2009 & 2.58 & 1.61 & 0.62 & 33.6 \\
2011 & 1.31 & 1.04 & 0.79 & 28.6 \\
2012 & 1.65 & 1.33 & 0.80 & 29.9 \\
Mean & 1.88 & 1.33 & 0.72 & 31.3 \\
Range & 1.27 & 0.57 & 0.18 & 5.0 \\
$\sigma$ & 0.42 & 0.18 & 0.07 & 1.85 \\
CV & 0.22 & 0.14 & 0.10 & 0.06 \\
\hline
\end{tabular}

Lehning, 2011), scale breaks in the order of meters to tens of meters are expected. Considering this length characteristic we calculate omni-directional variograms with $2 \mathrm{~m}$ grid spacing. The lag distance $h$ is subdivided into 20 log-spaced bins for each power of ten. The maximum $h$ is set to $200 \mathrm{~m}$ for ice-free terrain. With respect to the more homogeneous snow cover on glaciers, semivariance is calculated with a maximum $h=1000 \mathrm{~m}$ for small glaciers and of $h=3000 \mathrm{~m}$ for the two large glaciers, HEF and KWF.

For ice-free terrain, a preliminary first break distance $L_{p}$ is calculated by automatically fitting an exponential function to $h$ and using a threshold of $95 \%$ of $\gamma\left(h_{k}\right)$ (Webster and Oliver, 2007). This automatically fitted $L$ is only used to separate the data of the used bins into a short-range set and a long-range set. Power laws are fitted to the two datasets in the log-transformed variogram, solving least squares to calculate the short-range fractal dimension, $D_{\mathrm{s}}$, for $h \leq L_{\mathrm{p}}$ and the long-range fractal dimension, $D_{\mathrm{l}}$, for $h>L_{\mathrm{p}}$. The intersection of the two fitted lines presents the final $L$, which depends on the slope of the power laws and differs from $L_{p}$. In contrast to Shook and Gray (1996), who used a fixed $D_{\mathrm{l}}=3$ (completely random spatial distribution), we also calculated $D_{1}$ for the long-range section.

\section{RESULTS}

\section{Spatial and temporal snow distribution}

Mean snow depth at the end of each accumulation season, $\overline{H S}$, and its spatial and temporal variability are shown in Table 3. $\overline{H S}$ ranged from $1.31 \mathrm{~m}$ in 2011 to $2.58 \mathrm{~m}$ in 2009. This range corresponds to $68 \%$ of the temporal mean, $\overline{H S}$, of $1.88 \mathrm{~m}$. Whereas the temporal $\mathrm{CV}$ of $\overline{H S}$ and the long-term temporal CV of winter precipitation measured at cumulative gauges in the investigated catchment (Table 2) are similar, the observed range between minimum and maximum winter precipitation is higher than the range of $\overline{H S}$ in the five investigated years.

Snow-covered area, SCA, varied interannually by $16 \%$ of its mean value. The temporal mean snow-covered area fraction was $87 \%$ of the total area. The standard deviation of spatially distributed $H S\left(\sigma_{H S}\right)$ was lowest in the year of minimum $\overline{H S}, 2011 . \sigma_{H S}$ was similar in 2002, 2003 and 


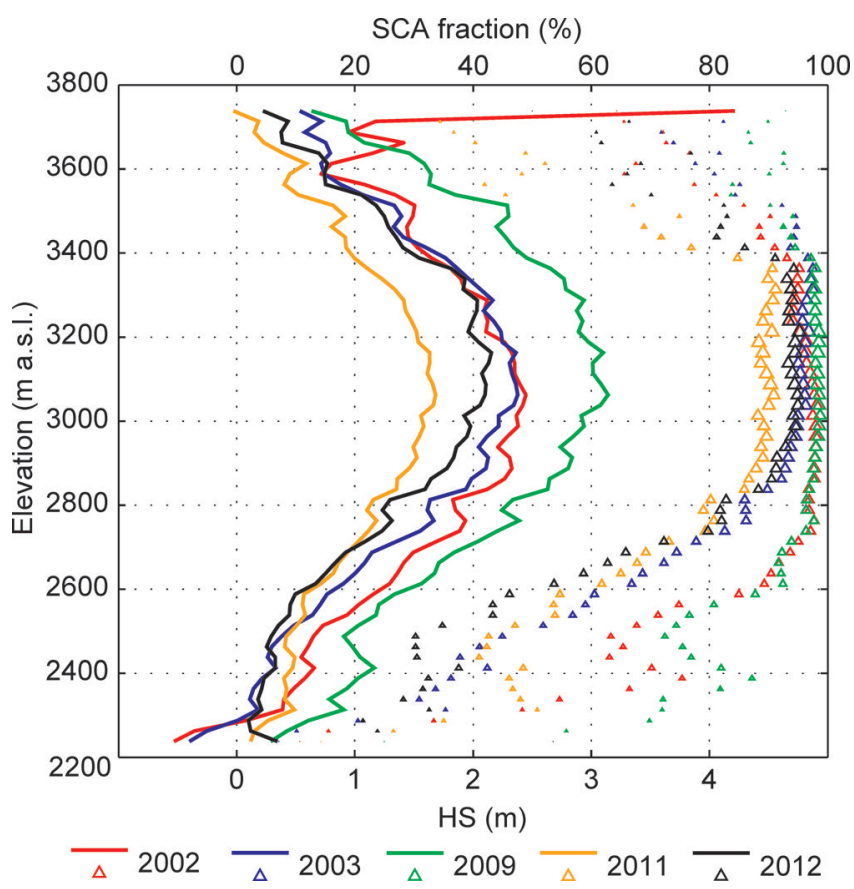

Fig. 3. Mean snow depth, HS (solid lines), and SCA fraction (triangles) of $25 \mathrm{~m}$ elevation zones. The size of the triangles represents the area of the corresponding elevation zone scaled by the total investigation area, i.e. small triangles represent only small areas with less contribution to total snow-cover volume compared with the contribution from areas marked with large triangles.

2012. In these years, the spatial CV varies due to interannual variations in $\overline{H S}$. Maximum $\sigma_{H S}$ occurred in 2009, whereas the spatial $\mathrm{CV}$ was lowest in this year of highest $\overline{H S}$. This shows the great influence of $\overline{H S}$ on the spatial $\mathrm{CV}$ of one year compared with the influence of $\sigma_{H S}$. The mean spatial $\mathrm{CV}$ of $\overline{H S}$ was 0.72 . The temporal $\mathrm{CV}$ shows that $\overline{H S}$ was interannually more variable than $\sigma_{H S}$ and the spatial $\mathrm{CV}$.

Pearson correlation coefficients ( $r$; Table 4$)$ of spatially distributed $H S$ show a high correlation of $H S$ between all accumulation seasons. At the high spatial resolution of $1 \mathrm{~m}$, $r$ is highest for the two seasons with a high fraction of snowfree area in 2011 and 2012 and second highest for the two seasons of the lowest $\overline{H S}$ in 2011 and the highest $\overline{H S}$ in 2009. The correlations are lower for combinations that include the HS distributions of 2002 and 2003. Thus, there is no clear dependence of correlation on $\overline{H S}$. In general, correlations of $H S$ distributions decrease with increasing time lag between the two seasons. At a spatial resolution of $100 \mathrm{~m}$, correlations between the HS distribution of 2003 and later years are similar, but correlations including $H S$ distributions of 2002 still show lower values. In general, an increase in correlation with decrease in raster resolution is obvious, due to a reduction in small-scale variability by spatial aggregation, as shown by, for example, Melvold and Skaugen (2013).

A high Pearson correlation $(r=0.94)$ was found between $\overline{H S}$ and SCA with lower $\overline{H S}$, indicating less SCA. This is clear from Figure 3, where mean $H S$ and SCA fraction of the investigated years are shown for $25 \mathrm{~m}$ elevation zones. In this figure, large triangles represent elevation zones with a large area and, thus, a high contribution to total snow-cover volume compared to elevation zones marked with small triangles. In these elevations of largest contribution to total

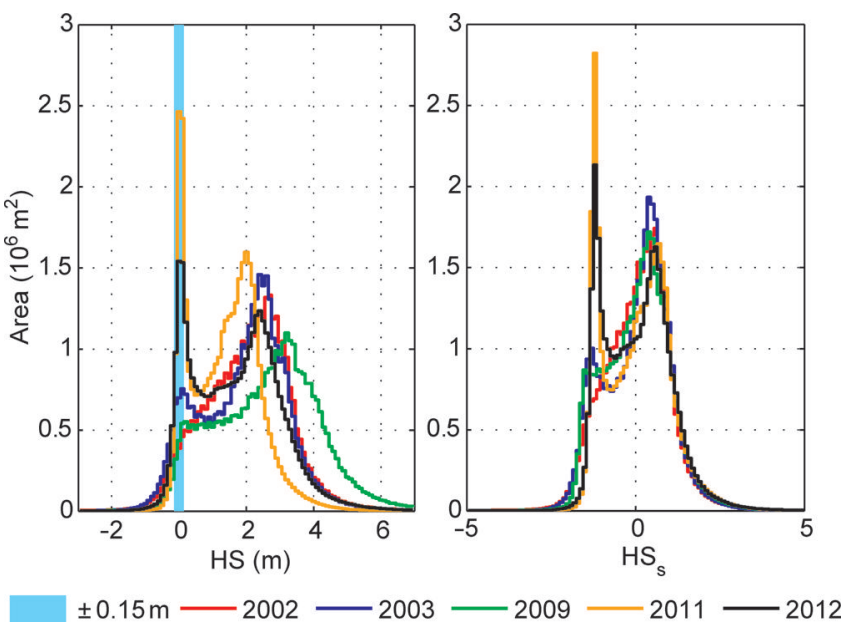

Fig. 4. Frequency distribution of snow depth, $H S$, and standardized snow depth, $H S_{\mathrm{s}}$ (Eqns (1) and (2)), for the five accumulation seasons. The uncertainty of ALS data $( \pm 0.15 \mathrm{~m})$ is shaded in blue at $H S=0$.

catchment area, HS varied by a factor of two, whereas SCA fraction varied by only $11 \%$ (between $87 \%$ in 2011 and $98 \%$ in 2009).

In general, the annual elevation distribution of $H S$ and SCA fraction seem to run parallel (Fig. 3). HS increased to an elevation of $3100 \mathrm{~m}$ a.s.l. and decreased above $3200 \mathrm{~m}$ a.s.l. Interannual differences of $H S$ and SCA fraction can be found at the lowest elevations and at mountain ridges $>3400 \mathrm{~m}$ a.s.l. Differences in mean HS of up to $0.5 \mathrm{~m}$ occurred for interannually similar SCA fractions $<2800 \mathrm{~m}$ a.s.l. (i.e. 2002 and 2009).

The remarkably high fraction of snow-free areas in 2011 and 2012 is clear at $H S=0 \pm 0.15 \mathrm{~m}$ in Figure 4. The year with lowest $\overline{H S}$ (2011) shows a peak of most frequent $H S$ at $2 \mathrm{~m}$. In contrast, the year with highest $\overline{H S}$ (2009) has a peak of most frequent $H S$ at $3.2 \mathrm{~m}$. Frequency distributions of standardized snow depths, $H S_{s}$, were found to be interannually more consistent than frequency distributions of $H S$. Hence, $H S_{s}$ was chosen to distinguish between areas of persistent snow cover and areas of high interannual snow depth variability.

The temporal mean of $H S_{s}$ (Fig. 5a) represents the standard snow pattern in the investigation area using the available ALS data. South-facing slopes at lower elevations

Table 4. Correlation coefficients, $r$, of spatially distributed $H S$ calculated in raster resolutions from 1 to $100 \mathrm{~m}$ for each possible combination of the individual accumulation seasons

\begin{tabular}{llllll}
\hline & $1 \mathrm{~m}$ & $10 \mathrm{~m}$ & $30 \mathrm{~m}$ & $50 \mathrm{~m}$ & $100 \mathrm{~m}$ \\
\hline $2002 / 2003$ & 0.68 & 0.77 & 0.82 & 0.84 & 0.86 \\
$2002 / 2009$ & 0.64 & 0.72 & 0.76 & 0.78 & 0.81 \\
$2002 / 2011$ & 0.62 & 0.70 & 0.75 & 0.78 & 0.82 \\
$2002 / 2012$ & 0.64 & 0.73 & 0.78 & 0.81 & 0.85 \\
$2003 / 2009$ & 0.74 & 0.81 & 0.85 & 0.87 & 0.89 \\
$2003 / 2011$ & 0.74 & 0.81 & 0.85 & 0.87 & 0.90 \\
$2003 / 2012$ & 0.71 & 0.79 & 0.83 & 0.85 & 0.88 \\
$2009 / 2011$ & 0.82 & 0.87 & 0.89 & 0.90 & 0.92 \\
$2009 / 2012$ & 0.79 & 0.84 & 0.87 & 0.88 & 0.89 \\
$2011 / 2012$ & 0.84 & 0.87 & 0.89 & 0.90 & 0.91
\end{tabular}



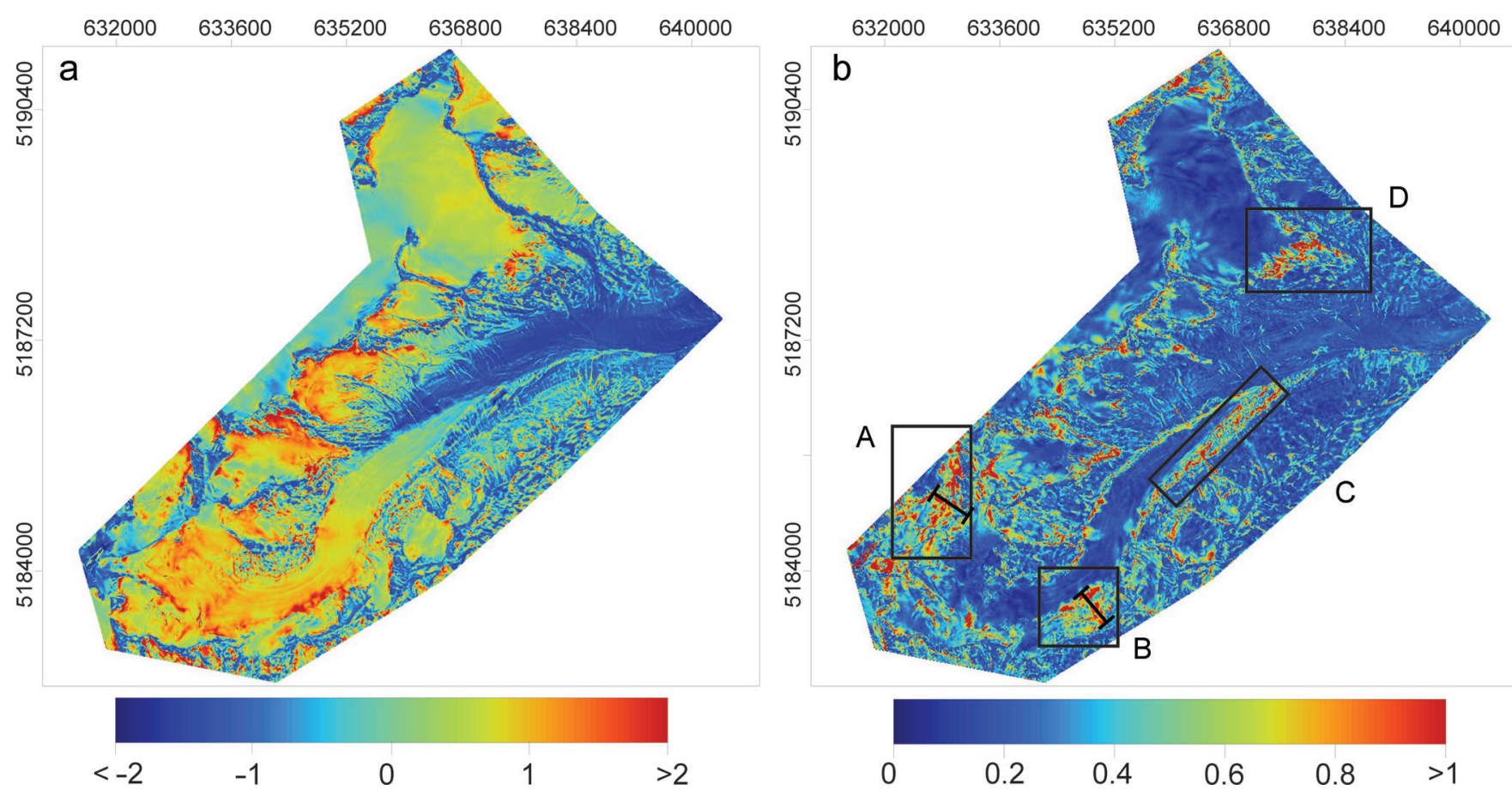

Fig. 5. Spatial distribution of (a) temporal mean standardized snow depth, $H S_{s}$, and (b) its interannual standard deviation, $\sigma H S_{s}$, for all five accumulation seasons. A, B, C and D mark regions of high interannual variation of $H S_{\text {s }}$.

showed almost no snow cover at the time of $\operatorname{ALS}(t 2)$. At higher elevations, low snow coverage can be found at sheer rock faces and along mountain crests. In general, $H S_{\mathrm{s}}$ on the glacier surfaces was higher than $H S_{s}$ in ice-free areas. Increased $H S_{\mathrm{s}}$ can be found at the base of steep slopes and along the glacier margins. These are the areas of high temporal standard deviation of $H S_{\mathrm{s}}\left(\sigma H S_{\mathrm{s}}\right)$ with respect to the available ALS data.

Areas $\mathrm{A}$ and $\mathrm{B}$ in Figure $5 \mathrm{~b}$ are examples of regions showing high $\sigma H S_{\mathrm{s}}$ as a result of avalanche release and accumulation. Corresponding profiles of $H S$ are shown in Figure 6. In both areas, HS for 2002 is low at steep slopes and

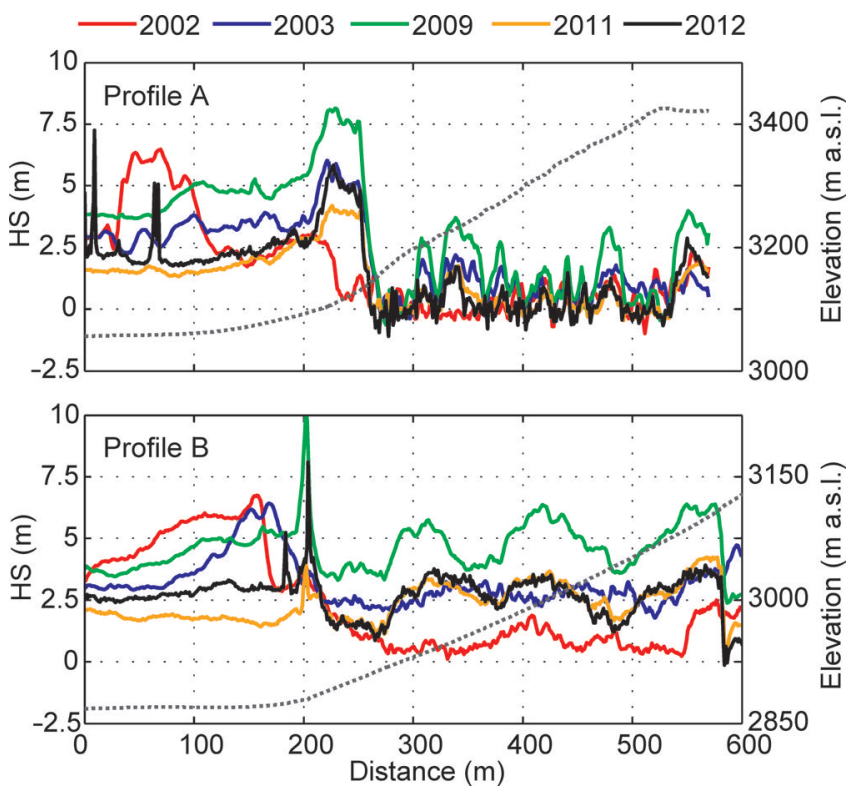

Fig. 6. Snow depth $H S$ along profiles A and B (Fig. 5b) for the five accumulation seasons. The dotted lines show the corresponding mean elevation of the ALS(t1) surface (right axis). high on glacier surfaces within $\sim 100 \mathrm{~m}$ of the slope base. In profile A, high $H S$ can be found directly at the slope base in the other years. Peaks of $H S$ at a distances between 0 and $100 \mathrm{~m}$ in profile A and at $200 \mathrm{~m}$ in profile B are caused by crevasses at the $\mathrm{ALS}(t 1)$ reference surface. A substantial snow volume was kept on the slope in area B (Fig. 6b) and not released to the glacier surface prior to ALS(t2) in 2009. Box C highlights a typical dead-ice area next to the tongue of Hintereisferner (investigated by, e.g., Bollmann and others, 2011; Sailer and others, 2012). In dead-ice zones, the high temporal variability of $H S_{\mathrm{s}}$ results from spatially differing surface lowering within the 10 year period. The retreat of the glacier tongue of Kesselwandferner in the 10 year period caused a high interannual variability of $H S_{\mathrm{S}}$ in box $\mathrm{D}$ (see also next subsection). In contrast to zones A-D, large parts of the investigation area have low $\sigma H S_{\mathrm{s}}$, which is indicated by the dominant blue color graduation in Figure $5 \mathrm{~b}$. An area fraction of $75 \%$ corresponds to a threshold $\sigma H S_{\mathrm{s}}$ of 0.4 (Fig. 7). This large section is characterized by an interannually persistent $H S_{\mathrm{s}}$. Conversely, about a quarter of the total area shows a high interannual variability of $H S_{\mathrm{s}}$. These areas were found to be not necessarily located in steep terrain, and are more frequent at the base of steep slopes and along glacier margins (Figs 1 and 5).

The multi-annual cross-combination of squared errors of $H S_{\mathrm{s}}\left(\mathrm{SE}_{\mathrm{s}} ; \mathrm{Eqn}(3)\right)$ helps in analysis of the temporal frequency of the processes causing high interannual variability of snow depths, and to explain the magnitude of spatial means of $\mathrm{SE}_{\mathrm{S}}$ $\left(\mathrm{MSE}_{\mathrm{s}}\right.$; Fig. 8). Most parts of the areas featuring $\mathrm{SE}_{\mathrm{S}}<0.5$ (masked white in Fig. 8) correspond to areas of $\sigma H S_{\mathrm{s}}<0.4$ (Fig. 5b).

High $\mathrm{SE}_{\mathrm{S}}$ are clear within areas $\mathrm{A}$ and $\mathrm{B}$ (Fig. 8, upper row), where snow variability is a result of the release and accumulation of avalanches (Fig. 6). These interannual differences of $H S_{\mathrm{s}}$ are especially pronounced in combinations that include 2002. High $\mathrm{SE}_{\mathrm{s}}$ between the years 2002, 2003 and the more recent surveys 2009, 2011 and 2012 are 
clear for areas $\mathrm{C}$ and $\mathrm{D}$ along the glacier margins. In these areas, high values of $\mathrm{SE}_{\mathrm{s}}$ are caused by continuous changes in topography, due to melt of dead ice, collapse of moraines and glacier retreat within at least 6 years between the surveys (e.g. Fischer, 2011; Sailer and others, 2012). Thus, $\mathrm{MSE}_{\mathrm{s}}$ (Fig. 8) and correlation coefficients ( $r$; Table 4) are highest for cross-combinations including 2002 and lower for shorter time lags between the years. Even in the 2 year period 2009-11 and the 3 year period 2009-12, high $\mathrm{SE}_{\mathrm{s}}$ can be found along the glacier margins (Fig. 5b, box C). $\mathrm{SE}_{\mathrm{s}}$ values along the glacier margins are small for the 1 year periods 2002/03 and 2011/12, which reduces $\mathrm{MSE}_{\mathrm{s}}$ for these cross-combinations.

\section{Residual analysis}

While high interannual variability was detected for areas along the glacier margins, it has not yet been shown what causes the interannual variability of $\mathrm{SE}_{\mathrm{s}}$ in these zones. The temporal clustering of the residuals of each $H S$ value from its surrounding mean $\left(r_{H S}\right.$; Eqn (4)) is applied to show more detail of the differences in the areas highlighted in the previous subsection. The clustering of $r_{H S}$ resulted in seven

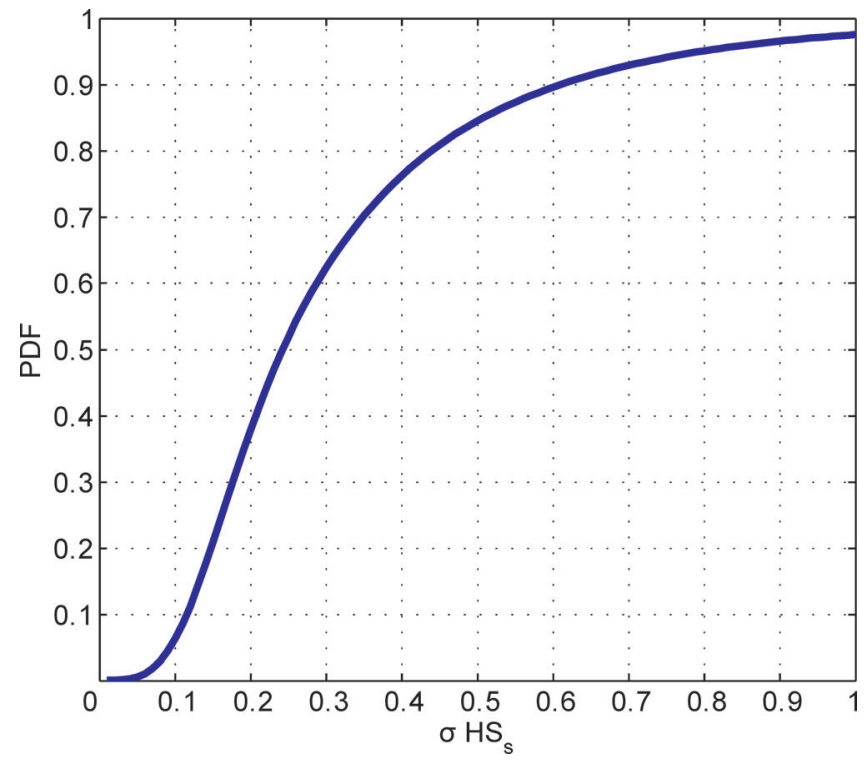

Fig. 7. Cumulative probability density function (PDF) of the temporal standard deviation of standardized snow depths, $\sigma H S_{\mathrm{s}}$.

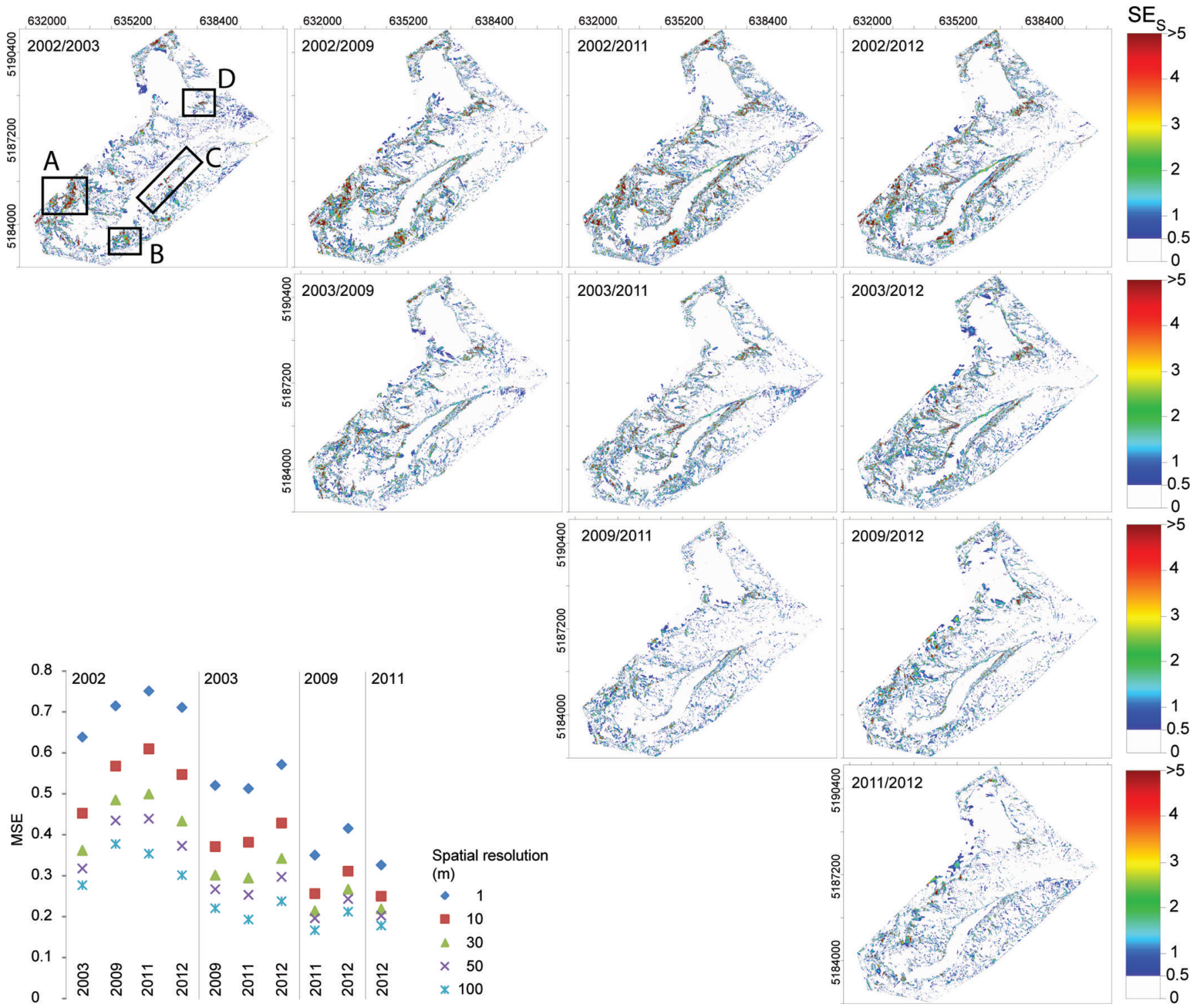

Fig. 8. Maps of squared errors of standardized snow depths, $\mathrm{SE}_{\mathrm{s}}($ Eqn (3)), between all possible combinations of the five accumulation seasons. In the lower-left corner, mean squared errors, MSE, of the cross-combinations are shown for different spatial resolutions. 

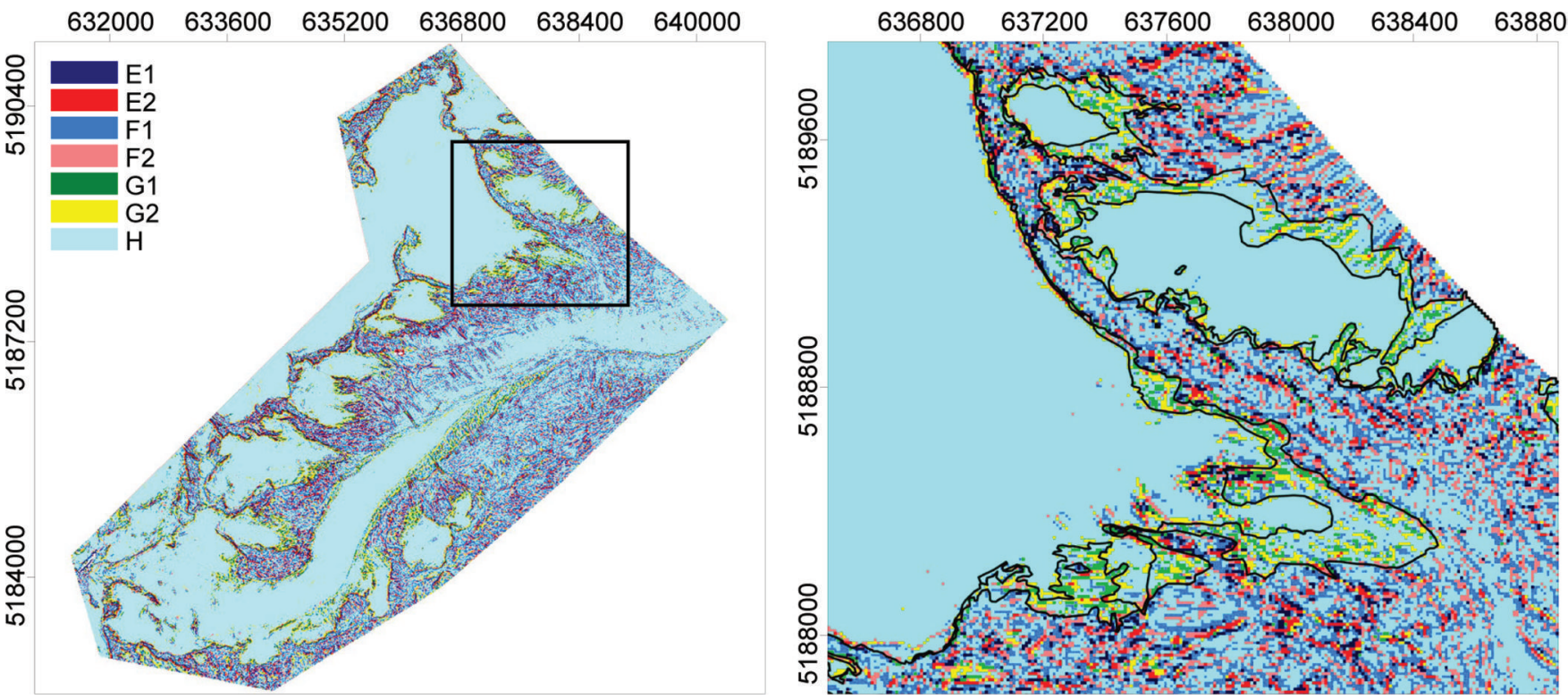

Fig. 9. Clusters derived by $k$-means clustering of snow depth residuals, $r_{H S}$. The letters pair classes with similar temporal characteristics in magnitude of $r_{H S}$. Index 1 indicates negative $r_{H S}$ and index 2 indicates positive $r_{H S}$. The detailed view highlights areas of changes in snow accumulation as a result of glacier retreat (black glacier outlines) in the 10 year period 2001-11.

classes. Three of the ten initial classes are not discussed further because they originate from extreme values of individual seasons and cover only a small relative fraction $(0.1 \%)$ of the total area. A map of the clusters with a zoom to the area of the tongue of KWF is shown in Figure 9.
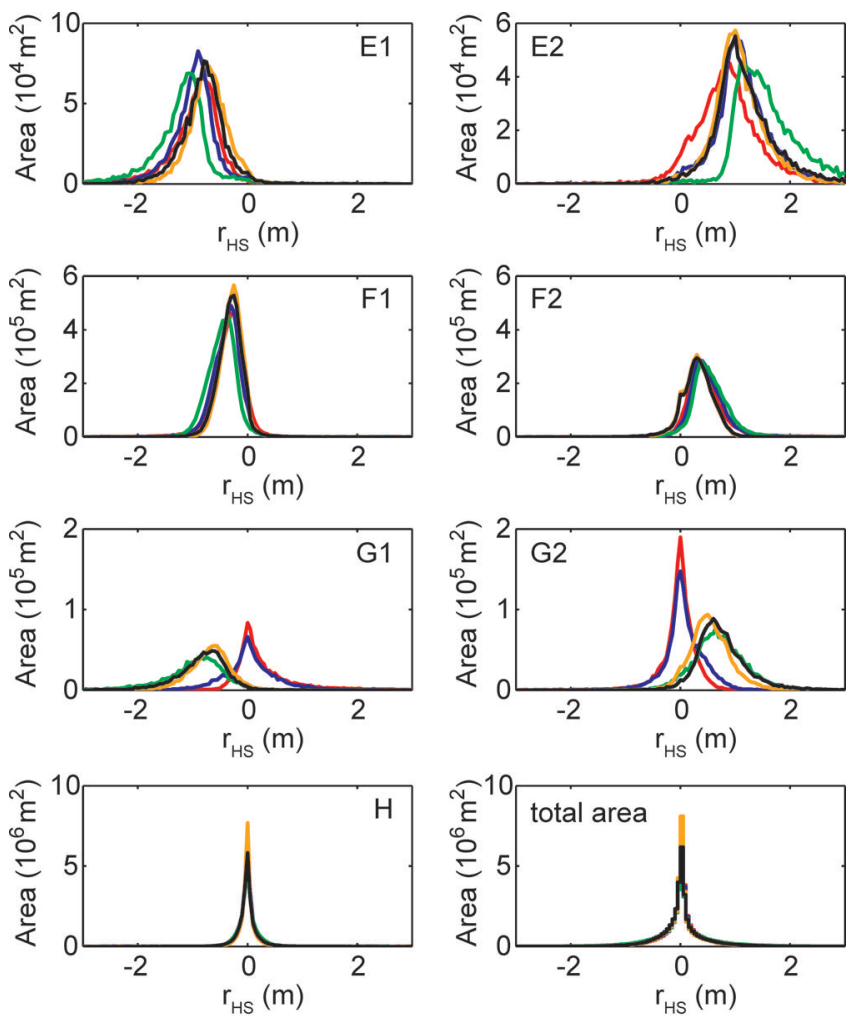

$-2002-2003-2009-2011-2012$

Fig. 10. Histograms of annual $r_{H S}$ for the clusters derived by $k$-means clustering of snow depth residuals, $r_{H S}$. Letters $\mathrm{E}-\mathrm{H}$ are the classes shown in Figure 9. Note that the scales on the area axes vary between the classes.
Figure 10 shows the frequency distribution of $r_{H S}$ within the classes $\mathrm{E}-\mathrm{H}$ and for the total area. Sixty-three percent $\left(22.5 \mathrm{~km}^{2}\right)$ of the investigated area is characterized by a homogeneous snow cover, predominantly located on glaciers and in areas with no snow in any of the five years (class $\mathrm{H})$. In these areas the mean $r_{H S}$ values are close to zero (maximum $\sigma=0.18 \mathrm{~m}$ ) in all five accumulation seasons. The transition zone from homogeneous $\left(r_{H S} \cong 0\right.$ ) to heterogeneous $\left(r_{H S} \neq 0\right)$ snow distribution (class F1 and F2) covers $25 \%$ of the total area. Frequency distributions of $r_{H S}$ in $\mathrm{F} 1$ and F2 were similar for the individual accumulation seasons (Fig. 10). More interannual variability of $r_{H S}$ is clear in classes E1 and E2 of distinct positive and negative $r_{H S}$ (Fig. 10). Maximum and minimum $r_{H S}$ were both found in 2009. This shows that the spatial variability of $H S$ increases in years of high $\overline{H S}$, i.e. $H S$ increases in sinks and channels, whereas crests and bumps remain snow-free. In 2002, the frequency distribution of $r_{H S}$ shifted towards lower values in areas of positive $r_{H S}$ (Fig. 10). This resulted from a snow cover accumulated at the mountain crests prior to $\operatorname{ALS}(t 1)$. Classes G1 and G2 are characterized by a change in $r_{H S}$ within the five accumulation seasons. These two classes are located at the glacier margins (Fig. 9) and together cover 6\% of the total area. They show homogeneous snow cover in 2002 and 2003, but distinct positive or negative $r_{H S}$ in 2009, 2011 and 2012 (Fig. 10). This change is a result of glacier retreat, which exposes the more heterogeneous surface of the former glacier bed compared with the homogeneous glacier surface. However, differences in these two classes are not visible in the frequency distribution of $r_{H S}$ for the total area, due to the large fraction of homogeneous snow cover (class $\mathrm{H}$ ) within the investigation area.

\section{Geostatistical analysis}

Variograms were calculated for $H S$ in ice-free terrain, for $H S$ on Hintereisferner (HEF) and Kesselwandferner (KWF) and for $H S$ on the remaining small glaciers (Fig. 11). The scale break, $L$, the corresponding sill, $\gamma\left(h_{L}\right)$, the short-range fractal 
dimension, $D_{\mathrm{s}}$, and the long-range fractal dimension, $D_{\mathrm{l}}$, were calculated for ice-free terrain (Table 5).

An interannually consistent $L$ was found in ice-free terrain at $\sim 20 \mathrm{~m}$, whereas $\gamma\left(h_{L}\right)$ ranged considerably between the two years of lowest and highest $\overline{H S}$ (Table 5). The shortrange variability of $H S$ is highest in 2002 (Fig. 11a). This results in a higher $D_{\mathrm{s}}$ than the interannually persistent $D_{\mathrm{s}}$ of the other four years (Table 5). In all five years, the increase of $\gamma(h)$ with $h$ flattens out to a consistent $D_{\text {I }}$ of 2.9 for $H S$ in ice-free terrain. $\gamma(h)$ for $h>L$ depends on the spatial mean snow depth, $\overline{H S}$, of the individual years with increasing $\gamma(h)$ for increasing $\overline{H S}$.

In contrast, no distinct flattening of $\gamma(h)$ with increasing $h$ could be found for $h>10 \mathrm{~m}$ on the glacier surface. The overall spatial variability of $H S$ in ice-free terrain was found to be higher than $\gamma(h)$ on glaciers. A break in scaling behavior of $H S$ on glaciers is indicated at $L=10 \mathrm{~m}$ (Fig. 11b-d). However, $\gamma(h)$ is of the magnitude of a few centimeters to one decimeter at $h=10 \mathrm{~m}$ and, thus, in the range of the assumed accuracy of $\Delta z_{\mathrm{ALS}}$. At $h=10 \mathrm{~m}, \gamma(h)$ is slightly higher on HEF than on small glaciers and on KWF.
Table 5. Annual scale break, $L$, the corresponding sill, $\gamma(L)$, shortrange fractal dimension, $D_{\mathrm{s}}$, and long-range fractal dimension, $D_{\mathrm{l}}$, calculated for $H S$ in ice-free terrain

\begin{tabular}{lccccc}
\hline & 2002 & 2003 & 2009 & 2011 & 2012 \\
\hline$L(\mathrm{~m})$ & 18.0 & 19.7 & 19.8 & 20.4 & 21.7 \\
$\gamma(L)(\mathrm{m})$ & 0.92 & 0.75 & 1.27 & 0.54 & 0.64 \\
$D_{\mathrm{s}}$ & 2.66 & 2.45 & 2.44 & 2.34 & 2.43 \\
$D_{\mathrm{l}}$ & 2.93 & 2.93 & 2.92 & 2.92 & 2.91 \\
\hline
\end{tabular}

At scales of $h<10 \mathrm{~m}, \gamma(h)$ is highest in 2003 and 2012 on all glaciers. Although $\gamma(h)$ of $H S$ is lowest in 2011, differences can be found between $\gamma(h)$ in different accumulation seasons on the glaciers. In particular, HS in 2002 shows low variability at shorter scales, but $\gamma(h)$ increases towards scales of $\sim 100 \mathrm{~m}$ on small glaciers and on HEF. However, variability of $H S$ in 2002 stays at comparatively low values on KWF. The variability of $H S$ on KWF in 2003 does not increase over a large range of $h$.
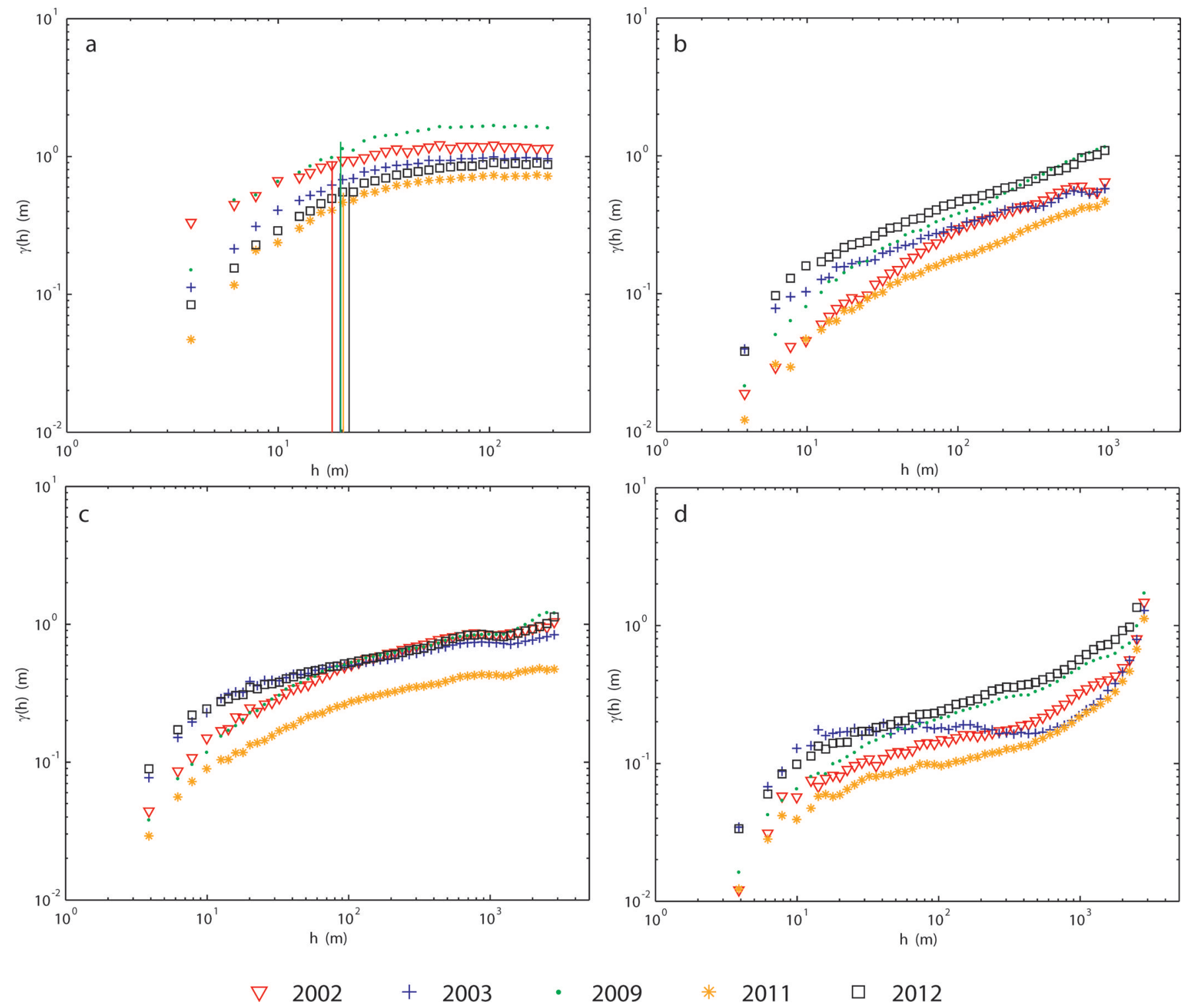

Fig. 11. Variograms for $H S$ of the five accumulation seasons. (a) In ice-free terrain, (b) on small glaciers, (c) on Hintereisferner and (d) on Kesselwandferner. Vertical lines in (a) show the location of the calculated scale breaks, $L$. 


\section{DISCUSSION}

\section{Spatial and temporal snow distribution}

The interannual analysis of the snow cover in this partly glacierized catchment shows a higher range of $\overline{H S}(68 \%$ of its temporal mean) compared with the interannual range of SCA $(16 \%$ of its temporal mean; Table 3$)$. Nevertheless, annual SCA and $\overline{H S}$ of the total area have a high correlation $(r=0.94)$. With respect to the total snow-cover volume, and hence $\overline{H S}$, elevations of the largest area present a roughly parallel shift in elevation distribution of $H S$ and SCA (Fig. 3). But differences in SCA fraction are small at these elevations. This is a result of the large fraction of glacierized area that is totally snow-covered in all years. At lower elevations, snowmelt caused different $H S$ and variable SCA, due to the seasonal course of weather conditions. However, variable $H S$ at these elevations has less influence on $\overline{H S}$, due to their small area fraction. The small variation of SCA compared with the variation of $\overline{H S}$ might be challenging for the determination of relationships between snow-covered area fraction and snow depths, such as those used to calculate subgrid variability of snow-cover products from satellite data (e.g. Swenson and Lawrence, 2012) or to model spatial variability of snow depths (e.g. Luce and others, 1999; Liston, 2004; Clark and others, 2011). At the time of peak snow accumulation, very detailed surveys of SCA over the largest-area elevation zones would be necessary to obtain mean snow depth of the partly glacierized catchment from small changes in SCA.

As a result of ice flow and densification of firn, HS can be underestimated in typical firn areas of the glaciers. This is more relevant for elevations $>3250$ ma.s.l. Helfricht and others (2014) compared ALS data and ground-penetrating radar measurements on the investigated glaciers and found a mean underestimation of $H S$ of $0.4 \mathrm{~m}(\sigma=0.34 \mathrm{~m})$ by ALS data in the firn areas of the glaciers. The decrease of mean $H S$ in glacierized areas $>3250$ ma.s.l. (Fig. 3) can partly result from firn densification and ice dynamics. Areas of emergent ice flow were found to be small, having no considerable influence on the interpretation of HS. However, we assumed these dynamical processes to be constant in time, so no corrections were applied. Further, in many studies rough and steep surfaces were found to store less snow on average (Blöschl and Kirnbauer, 1992; Grünewald and Lehning, 2011; Helfricht and others, 2012; Grünewald and others, 2013; Schöber and others, in press).

An increase in annual $\sigma_{H S}$ with increasing $\overline{H S}$ was found. This was also noted by Sturm and Wagner (2010), who analyzed $\overline{H S}$ derived from snow depth samples taken on a regular $30 \mathrm{~m}$ grid within a $1 \mathrm{~km} \times 1 \mathrm{~km}$ Arctic test area. Melvold and Skaugen (2013) also found a decreasing spatial $\mathrm{CV}$ with increasing $H S$ with values between 0.86 $(\overline{H S}=1.42 \mathrm{~m})$ and $0.62(\overline{H S}=2.89 \mathrm{~m})$. Winstral and Marks (2014) discussed the variation of spatial CV when $\overline{H S}$ changes at a faster rate than $\sigma$. In their study, the mean spatial CV over 11 years was 0.71 , with a slightly higher value for snow surveys in spring (0.81). This finding is in agreement with the variability in mean spatial CV found in our study. Winstral and Marks (2014) also found a high spatial CV, of 0.89 , for 1 year ALS data. Winstral and Marks (2014) related higher spatial CV of HS to higher wind speeds and higher melt rates. To some degree this might be true for the spatial CV of HS reported here, in 2011 and 2012, when potential melt conditions appeared prior to $\operatorname{ALS}(t 2)$.
Marchand and Killingtveit (2005) showed that the spatial $\mathrm{CV}$ is in the range $0.72-0.96$ for open sites in Norway. Jepsen and others (2012) analyzed a total of 5300 snow depth measurements taken at the end of 12 accumulation seasons. They found the spatial CV of the snow cover ranged from 0.73 to 1.09 in a continental Alpine watershed. In their study, the temporal variability of the spatial CV was 0.15 , which is higher than the temporal variability of $\mathrm{CV}$ of 0.1 found here. Grünewald and others (2010) derived a spatial CV of HS between 0.6 and 2.0 from terrestrial lidar data, with the lowest values at the beginning of the ablation season.

In general, the temporal mean spatial CV of ALS-derived $H S$ in this study $(0.72)$ is at the low end of values derived for open and high-elevation alpine areas in previous studies. Schöber and others (in press) present a map of spatially distributed CVs of HS in 2011, which includes the investigation area of the present study and shows low $\mathrm{CV}$ values on glaciers. Thus, with respect to the homogeneous snow cover on the glacier surface, annual and multi-annual mean spatial CVs of $H S$ in partly glacierized catchments tend to be lower than the CVs in ice-free terrain.

Here we find the maximum correlation across two years is $0.84(2011 / 2012)$ for the original spatial resolution of $1 \mathrm{~m}$. This is lower than interannual correlations found for $H S$ by Deems and others (2008) $(r=0.88-0.92)$, Melvold and Skaugen (2013) ( $r=0.95)$ or Schirmer and others (2011) (up to $r=0.97)$. This results from the large area and complex terrain investigated in our study. The wide range of snow depths (snow-free to $H S>5 \mathrm{~m}$ in avalanche accumulation areas), the high number of different topographic features (glaciers, rock walls, slopes, mountain crests, etc.) and the corresponding dynamical processes (glacier retreat, rockfall, collapse of moraines, etc.) reduce the interannual correlation compared with smaller, temporally more consistent test sites.

Since $H S$ is scaled for statistical models to simulate snowcover distribution (e.g. Sturm and Wagner, 2010; Lehning and others, 2011; Grünewald and others, 2013), different measures of snow depth have been used. We found standardized snow depth, $H S_{s}$, best suited to describe the interannual frequency distribution of $H S$ of this area. Thus, we used $H S_{\mathrm{s}}$ to distinguish between areas with interannually persistent snow cover and areas with high interannual variability. In the same way as Sturm and Wagner (2010), we showed a climatological snow distribution pattern in terms of spatially distributed, temporal mean $H S_{\mathrm{s}}$ of the investigated snow surveys. Although Sturm and Wagner (2010) found that interannually persistent areas were visually striking, they did not present a measure to differentiate between interannually variable $H S_{s}$ and areas of persistent snow cover. We used the temporal standard deviation of $H S_{\mathrm{s}}\left(\sigma H S_{\mathrm{s}}\right)$ (Fig. 5b) to demonstrate that $75 \%$ of the investigated area showed interannually consistent $H S_{\mathrm{s}}$ for a threshold $\sigma H S_{\mathrm{s}}$ of 0.4 .

In general, $\sigma H S_{\mathrm{s}}$ is low on glaciated areas and on gentle slopes (Fig. 5b). Especially in these areas, lidar measurements of HS have an appropriate accuracy and most of the snow-cover volume is accumulated there. Thus, ALS is suitable for recording characteristic snow depth distributions for the calibration and validation of hydro-meteorological models (e.g. Schöber and others, in press). High HS values were found consistently on glaciers characterized by flat, sheltered surfaces at high elevations. The preferential accumulation in these areas is also the reason why glaciers exist where they do. For instance, Dadic and others (2010a) 
related the location of glaciers to differences in the wind field. Redistribution of snow to glacier surfaces has already been included in hydro-meteorological models adapted to the investigated catchment (Kuhn, 2003).

The reduction of $\mathrm{MSE}_{\mathrm{s}}$ with increasing aggregation of raster resolution (Fig. 8) is distinctly higher for $\mathrm{MSE}_{\mathrm{s}}$ values that include 2002 or 2003 compared with $\mathrm{MSE}_{\mathrm{s}}$ calculated between surveys since 2009. Small-scale features of high $\mathrm{SE}_{\mathrm{s}}$ are smoothed, especially in narrow areas along sheer rock walls and glacier margins. Two studies have calculated mean-squared errors of $H S_{\mathrm{s}}\left(\mathrm{MSE}_{\mathrm{s}}\right)$ for multi-annual data. Sturm and Wagner (2010) found $H S_{\mathrm{s}}$ for snow surveys in March and April compared with one survey in March in the range 0.31-1.34. Lower $M S E_{s}$ values were found by Winstral and Marks (2014). Based on the snow depth data over 11 years at a spatial resolution of $30 \mathrm{~m}$, their calculated $\mathrm{MSE}_{\mathrm{s}}$ was in the range $0.06-0.6$, with a mean $M_{S} E_{s}$ of 0.31 . This range is comparable with the mean $\mathrm{MSE}_{\mathrm{s}}$ found in our study $(0.22-0.5)$ with a mean of 0.34 for a spatial resolution of $30 \mathrm{~m}$ (Fig. 8).

Areas of high interannual snow depth variability (i.e. high $\sigma H S_{\mathrm{s}}$ ) are not restricted to mountain crests and steep slopes, where ALS data are affected by large errors. In general, $82 \%$ of all $\sigma H S_{\mathrm{s}} \geq 0.4$ were located at slopes of $<40^{\circ}$. High $\sigma H S_{\mathrm{s}}$ values were found at gently inclined slope toes and on homogeneous glacier surfaces (Fig. 7). These are typical accumulation areas of gravitational snow transport by avalanches and snow sloughs.

Geomorphological processes continuously change the mountains' surface topography (Bollmann and others, 2011; Sailer and others, 2012). Thus, the variation in the reference surface at ALS $(t 1)$ affects snow depth variability. In addition, glacier retreat alters the surface relief from a more homogeneous surface to heterogeneous landforms featuring ridges and sinks, which lead to a heterogeneous snow depth distribution (Figs 9 and 10). This coincides with the findings of Lehning and others (2011) and Schirmer and others (2011), who demonstrated that topographic roughness controls snow-cover variability. The shift of the frequency distribution of $r_{H S}$ towards more positive and negative values in the year of highest mean snow depth (2009) shows that differences of $H S$ between preferential accumulation areas and areas with less or no snow increase with an increasing $\overline{H S}$.

\section{Scaling behavior of snow depths}

We assessed the multi-scaling behavior of $H S$ separated by a scale break distance, $L$, into a short-range fractal dimension, $D_{\mathrm{s}}$, and a long-range fractal dimension, $D_{1}$. In ice-free terrain, $L$ was found to be interannually consistent at $\sim 20 \mathrm{~m}$, comparable with the $L=17.3$ and $20.4 \mathrm{~m}$ found by Schirmer and Lehning (2011) for a cross-loaded slope (i.e. variable wind direction) in complex mountain terrain. However, $L$ found by Deems and others (2008) for the $H S$ distribution of two seasons in a forested, moderate-elevation terrain with low rolling topography $(L=15.5$ and $15.9 \mathrm{~m})$ and at an Alpine site above the tree line $(L=31.5$ and $26.4 \mathrm{~m}$ ) are slightly lower and slightly higher, respectively. Mott and others (2011a) presented very similar values to those found in this study for peak HS calculated from terrestrial laser scanning measurements in a small Alpine area $\left(L=20.4, D_{\mathrm{s}}=2.31\right)$, and Schirmer and Lehning (2011) showed a reduction in $D_{\mathrm{s}}$ towards values between 2.3 and 2.5 at the end of the accumulation season. $D_{1}$ was found to be consistently close to 2.9 in all studies.
Here we found that $L$ determined for $H S$ in ice-free terrain marked the beginning of a curve-like reduction in the increase of $\gamma(h)$, rather than a distinct bend in $\gamma(h)$, unlike, for instance, those found by Mott and others (2011a) and Schirmer and Lehning (2011). This is a result of the large area $\left(\sim 14 \mathrm{~km}^{2}\right)$ and the high number of different surface types (rocks, boulders, talus, etc.) in a complex topography (sheer walls, gentle slopes, flat valley floors) with different exposure to meteorological conditions (radiation, wind). Since values of $L$ depend strongly on the bin spacing, the grid resolution, the area considered for the variogram and the maximum range of $h$ used for calculation, they give an order of magnitude (here a few tenths of a meter) rather than exact values.

We found $\gamma(h)$ of $H S$ at $h=2 \mathrm{~m}$ is highest in 2002 $(0.23 \mathrm{~m})$ and stays high for $h$ lower than the scale break, $L$ (Fig. 11a). Whereas $\gamma(h)$ at $h<4 \mathrm{~m}$ might be influenced by the accuracy of the ALS data (Section 2), similarities between snow-cover distribution in 2002 and 2009 can also be found in SCA and HS at lower elevations (Fig. 3). In addition, the avalanche activity in 2002 (Fig. 7) increased the small-scale variability of $H S$. No distinct, interannually persistent scale break could be detected on glaciers. Nevertheless, the increase in $\gamma(h)$ appeared to be higher at scales below $10^{-1} \mathrm{~m}$ compared with the increase in $\gamma(h)$ at larger $h$. Even though this variability is clear in some years, $\gamma(h)$ below $10^{-1} \mathrm{~m}$ is close to the accuracy of $\Delta z_{\mathrm{ALS}}$, of $\pm 0.15 \mathrm{~m}$ (Section 2). Thus, an interpretation of this scale break would be speculative. However, years without considerable snowfall prior to $\operatorname{ALS}(t 1)(2003,2012)$ show higher $\gamma(h)$ at short scales compared with years where snowfall occurred prior to the survey in autumn (see Section 3). This is a result of crevasses and surface structures, such as meltwater channels and moraines on the glacier surface which, if they are not covered by snow at $\operatorname{ALS}(t 1)$, increase small-scale variability.

Especially in 2011, $\gamma(h)$ of $H S$ was reduced over the whole range of $h$ due to snow accumulation prior to ALS $(t 1)$, the comparatively low precipitation over this season and the fact that melt had begun at the snow surface on the glaciers prior to $\operatorname{ALS}(t 2)$. The lower values of $\gamma(h)$ on glaciers in comparison with $\gamma(h)$ in ice-free terrain highlight the more homogeneous snow depth distribution on the ice surfaces.

\section{CONCLUSIONS}

In this paper we have reported a comprehensive analysis of the spatial distribution of the snow cover at the end of five accumulation seasons between 2002 and 2012 in a partly glacierized mountain catchment in Tyrol, Austria. The distribution of $H S$ at the end of the accumulation season is of great relevance for cryospheric and hydrologic studies, such as snowmelt modelling or seasonal glacier mass balances. The analysis makes it clear that the snow-covered area, SCA, is interannually much more persistent than the mean annual snow depths, $\overline{H S}$. Although a strong correlation was found between SCA and $\overline{H S}$, SCA varied only by $16 \%$ of its temporal mean, but $\overline{H S}$ varied by a factor of two in the five years. The interannual variability of $\overline{H S}$ in the five accumulation seasons $(C V=0.22)$ is of a similar magnitude to the climatic variability of winter precipitation in this region. Although five years of data do not make a 
climatic mean, the presented dataset - including one season of comparatively low $H S$ and one season of extremely high $H S$ - may provide a more reasonable base for statistical analysis and simulation of the snow depth distribution than data from single-year acquisitions. With respect to the statistical analysis, the frequency distribution of standardized snow depths was found to be more interannually consistent than the frequency distribution of absolute snow depths. Seventy-five percent of the investigated area was found to have an interannual standard deviation of standardized snow depth of $<0.4$ at a spatial scale of $10 \mathrm{~m}$ and, thus, can be interpreted as the standard snow pattern representing highly valuable information for snow-cover modelling in this area. The high interannual variability in snow depth in the remaining area is attributed to occasional avalanches, wind transport and changes in the surface topography. Especially areas associated with changes in glacierization were found to cause interannual snow depth variability. Ice melt in dead-ice bodies causes interannual variability in snow depth. A shift from homogeneous snow distribution towards a more heterogeneous snow cover was observed in areas that became ice-free, due to glacier retreat, within the investigated 10 year period. Compared with ice-free basins, this circumstance keeps the modelling of snow challenging with regard to the expected glacier retreat. So far, these changing zones cover only a low area fraction and still have a low impact with respect to (1) the total snow volume in the basin and (2) a coarse spatial resolution of the data, as typically used for modelling (e.g. 50-100 m). Nevertheless, areas of high interannual variability caused interannual differences in the correlation of snow depths which are even visible at a spatial resolution of $100 \mathrm{~m}$. Geostatistical analysis is performed to show interannual persistence of the scaling behavior of the mountain snow cover. The differences between spatial autocorrelation of $H S$ in ice-free terrain and spatial autocorrelation of $H S$ on glaciers show the great influence of glaciers on the snow depth variability in mountain catchments. Spatial variability of snow depth was found to depend on mean snow depth in ice-free terrain, but is influenced by the existence of a snow layer at $\operatorname{ALS}(t 1)$ on glacier surfaces. In agreement with typical scale breaks shown by other authors for HS in alpine areas at the end of the accumulation season (e.g. Deems and others, 2006; Mott and others, 2011a; Schirmer and Lehning, 2011), interannually persistent scale breaks at $20 \mathrm{~m}$ were detected in ice-free terrain of the total investigated catchment. On smooth glacier surfaces, the short- and long-range fractal characteristics cannot be easily distinguished, indicating scale-invariant behavior of $H S$ in such areas. However, disruptive surface structures (e.g. crevasses or meltwater channels) could turn the fractal parameters into length scales comparable with length scales in ice-free terrain. While our results in general confirm the fractal characteristics of HS indicated by other studies in ice-free terrain, these have so far only been shown for smaller areas. Fractal parameters calculated for irregular or small regular subareas may be a next step to obtain parameters for statistical snow models (e.g. Lehning and others, 2011) or deterministic snow models working in a gridded model layout. The present study shows, for the first time, the persistence and variability of the snow pattern for five accumulation seasons in a comparatively large catchment with a complex topography of ice-free terrain and glaciers.

\section{ACKNOWLEDGEMENTS}

This work was carried out within the framework of the alpSProject 'H03 MUSICALS A - Multiscale Snow/lce Melt Discharge Simulations for Alpine Reservoirs'. We thank the Austrian Research Promotion Agency (FFG) and the TIWAG - Tiroler Wasserkraft AG, who support this project. The ALS data used were acquired within the EU-financed OMEGAProject (Operational Monitoring System of European Glacial Areas, 5th Framework Programme: Environment and Sustainable Development, Development of generic Earth observation technologies, EVK-2-CT-2000-00069), the ALS-XProject (Kombination und Bewertung von flugzeuggestützten Laserscannerdaten und TerraSAR-X Daten für glaziologische und schneehydrologische Fragestellungen, FFGASAP 815527) financed by FFG, the C4AUSTRIA-Project (Climate Change Consequences for the Cryosphere, K09AC0K00073) financed by the Österreichischen Klima und Energie Fond and the project H03 MUSICALS A financed by TIWAG - Tiroler Wasserkraft AG and FFG. We thank TopScan GmbH (Rheine, Germany) for performing and processing the ALS surveys at high quality for many years. Also we appreciate the efforts of Thomas Grünewald and an anonymous referee, whose constructive comments and critical remarks helped to improve the paper.

\section{REFERENCES}

Abermann J, Fischer A, Lambrecht A and Geist T (2010) On the potential of very high-resolution repeat DEMs in glacial and periglacial environments. Cryosphere, 4(1), 53-65 (doi: 10.5194/tc-4-53-2010)

Achleitner S and 6 others (2012) Analyzing the operational performance of the hydrological models in an alpine flood forecasting system. J. Hydrol., 412-413, 90-100 (doi: 10.1016/j. jhydrol.2011.07.047)

Anderton SP, White SM and Alvera B (2004) Evaluation of spatial variability in snow water equivalent for a high mountain catchment. Hydrol. Process., 18(3), 435-453 (doi: 10.1002/ hyp.1319)

Baltsavias EP (1999) Airborne laser scanning: basic relations and formulas. ISPRS J. Photogramm. Remote Sens., 54(2-3), 199-214 (doi: 10.1016/S0924-2716(99)00015-5)

Bavay M, Grünewald T and Lehning M (2013) Response of snow cover and runoff to climate change in high Alpine catchments of Eastern Switzerland. Adv. Water Resour., 55, 4-16 (doi: 10.1016/j.advwatres.2012.12.009)

Blöschl G (1999) Scaling issues in snow hydrology. Hydrol. Process., 13(14-15), 2149-2175

Blöschl G and Kirnbauer R (1992) An analysis of snow cover patterns in a small alpine catchment. Hydrol. Process., 6(1), 99-109 (doi: 10.1002/hyp.3360060109)

Blöschl G, Gutknecht D and Kirnbauer R (1991) Distributed snowmelt simulations in an Alpine catchment. 2. Parameter study and model predictions. Water Resour. Res., 27(12), 31813188 (doi: 10.1029/91WR02251)

Bollmann E (2010) Airborne laser scanning glacier mass balance. Evaluation of airborne laser scanning glacier mass balance calculations at Hintereisferner (Tyrol, Austria). (Master's thesis, University of Innsbruck)

Bollmann E, Sailer R, Briese C, Stötter J and Fritzmann P (2011) Potential of airborne laser scanning for geomorphologic feature and process detection and quantifications in high alpine mountains. Z. Geomorph., 55(2), 83-104 (doi: 10.1127/03728854/2011/0055S2-0047)

Burrough PA (1993) Fractals and geostatistical methods in landscape studies. In Lam NSN and De Cola L eds. Fractals in geography. Prentice Hall, Englewood Cliffs, NJ, 87-121 
Clark MP and 8 others (2011) Representing spatial variability of snow water equivalent in hydrologic and land-surface models: a review. Water Resour. Res., 47(W7), W07539 (doi: 10.1029/ 2011WR010745)

Dadic R, Mott R, Lehning M and Burlando P (2010a) Wind influence on snow depth distribution and accumulation over glaciers. J. Geophys. Res., 115(F1), F01012 (doi: 10.1029/ 2009JF001261)

Dadic R, Mott R, Lehning M and Burlando P (2010b) Parameterization for wind-induced preferential deposition of snow. Hydrol. Process., 24(14), 1994-2006 (doi: 10.1002/hyp.7776)

Deems JS, Fassnacht SR and Elder K (2006) Fractal distribution of snow depth from LiDAR data. J. Hydromet., 7(2), 285-297 (doi: 10.1175/JHM487.1)

Deems JS, Fassnacht SR and Elder KJ (2008) Interannual consistency in fractal snow depth patterns at two Colorado mountain sites. J. Hydromet., 9(5), 977-988 (doi: 10.1175/2008JHM901.1)

Deems JS, Painter TH and Finnegan DC (2013) Lidar measurement of snow depth: a review. J. Glaciol., 59(215), 467-479 (doi: 10.3189/2013JoG12J154)

Elder K, Dozier J and Michaelsen J (1991) Snow accumulation and distribution in an alpine watershed. Water Resour. Res., 27(7), 1541-1552 (doi: 10.1029/91WR00506)

Fischer A (2010) Glaciers and climate change: interpretation of 50 years of direct mass balance of Hintereisferner. Global Planet. Change, 71(1-2), 13-26 (doi: 10.1016/j.gloplacha. 2009.11.014)

Fischer A (2011) Comparison of direct and geodetic mass balances on a multi-annual time scale. Cryosphere, 5(1), 107-124 (doi: 10.5194/tc-5-107-2011)

Fischer A, Markl G and Kuh M (2012) Glacier mass balance of Hintereisferner, Oetztal Alps, Austria, from 1952/53-2010/11. World Data Center for Climate (WDCC), Hamburg http://dx.doi. org/10.1594/WDCC/MB_HEF_1953-2011

Forgy EW (1965) Cluster analysis of multivariate data: efficiency versus interpretability of classifications. Biometrics, 21, 768-769

Fritzmann P, Höfle B, Vetter M, Sailer R, Stötter J and Bollmann E (2011) Surface classification based on multi-temporal airborne LiDAR intensity data in high mountain environments, a case study from Hintereisferner, Austria. Z. Geomorph., 55(2), 105126 (doi: 10.1127/0372-8854/2011/0055S2-0048)

Gao J and Xia Z (1996) Fractals in physical geography. Progr. Phys. Geogr., 20(2), 178-191 (doi: 10.1177/030913339602000204)

Geist T and Stötter J (2007) Documentation of glacier surface elevation change with multi-temporal airborne laser scanner data - case study: Hintereisferner and Kesselwandferner. Z. Gletscherkd. Glazialgeol., 41 77-106

Geist T, Elvehøy H, Jackson M and Stötter J (2005) Investigations on intra-annual elevation changes using multi-temporal airborne laser scanning data: case study Engabreen, Norway. Ann. Glaciol., 42, 195-201 (doi: 10.3189/172756405781812592)

Grünewald T and Lehning M (2011) Altitudinal dependency of snow amounts in two small alpine catchments: can catchmentwide snow amounts be estimated via single snow or precipitation stations? Ann. Glaciol., 52(58), 153-158 (doi: 10.3189/ 172756411797252248)

Grünewald T, Schirmer M, Mott R and Lehning M (2010) Spatial and temporal variability of snow depth and ablation rates in a small mountain catchment. Cryosphere, 4(2), 215-225 (doi: 10.5194/tc-4-215-2010)

Grünewald T and 9 others (2013) Statistical modelling of the snow depth distribution in open alpine terrain. Hydrol. Earth Syst. Sci., 17(8), 3005-3021 (doi: 10.5194/hess-17-3005-2013)

Hartigan JA and Wong MA (1979) A K-means clustering algorithm. J. R. Stat. Soc., Ser. C, 28(1), 100-108

Helfricht K, Schöber J, Seiser B, Fischer A, Stötter J and Kuhn M (2012) Snow accumulation of a high alpine catchment derived from LiDAR measurements. Adv. Geosci., 32, 31-39 (doi: 10.5194/adgeo-32-31-2012)
Helfricht K, Kuhn M, Keuschnig M and Heilig A (2014) Lidar snow cover studies on glaciers in the Ötztal Alps (Austria): comparison with snow depths calculated from GPR measurements. Cryosphere, 8(1), 41-57 (doi: 10.5194/tc-8-41-2014)

Hoinkes H (1970) Methoden und Möglichkeiten von Massenhaushaltsstudien auf Gletschern: Ergebnisse der Messreihe Hintereisferner (Ötztaler Alpen) 1953-1968. Z. Gletscherkd. Glazialgeol., 6(1-2), 37-90

Hopkinson C and 10 others (2001) Mapping the spatial distribution of snowpack depth beneath a variable forest canopy using airborne laser altimetry. In Hardy J and Frankenstein S eds. Proceedings of the 58th Eastern Snow Conference, May 17-19 2001, Ottawa, Ontario, Canada, 253-264 http://www. easternsnow.org/proceedings/2001/proceedings_index.html

Huss M, Farinotti D, Bauder A and Funk M (2008) Modelling runoff from highly glacierized alpine drainage basins in a changing climate. Hydrol. Process., 22(19), 3888-3902 (doi: 10.1002/ hyp.7055)

Huss M, Zemp M, Joerg PC and Salzmann N (2014) High uncertainty in 21 st century runoff projections from glacierized basins. J. Hydrol., 510, 35-48 (doi: 10.1016/j.jhydrol.2013.12.017)

Jepsen SM, Molotch NP, Williams MW, Rittger KE and Sickman JO (2012) Interannual variability of snowmelt in the Sierra Nevada and Rocky Mountains, United States: examples from two alpine watersheds. Water Resour. Res., 48(2), W02529 (doi: 10.1029/ 2011WR011006)

Jörg P, Fromm R, Sailer R and Schaffhauser A (2006) Measuring snow depth with a terrestrial laser ranging system. In Proceedings of the International Snow Science Workshop, 1-6 October 2006, Telluride, Colorado. International Snow Science Workshop, 452-460. CD-ROM

Joerg P, Morsdorf F and Zemp M (2012) Uncertainty assessment of multi-temporal airborne laser scanning data: a case study at an Alpine glacier. Remote Sens. Environ., 127, 118-129 (doi: 10.1016/j.rse.2012.08.012)

Kaser G, Fountain A and Jansson P (2003) A manual for monitoring the mass balance of mountain glaciers. (IHP-VI Technical Documents in Hydrology 59) UNESCO, Paris

Kuhn M (2003) Redistribution of snow and glacier mass balance from a hydrometeorological model. J. Hydrol., 282(1-4), 95-103 (doi: 10.1016/S0022-1694(03)00256-7)

Kuhn M, Dreiseitl E, Hofinger S, Markl G, Span N and Kaser G (1999) Measurements and models of the mass balance of Hintereisferner. Geogr. Ann. A, 81(4), 659-670

Lehning M, Löwe H, Ryser M and Radeschall N (2008) Inhomogeneous precipitation distribution and snow transport in steep terrain. Water Resour. Res., 44(W7), W07404 (doi: 10.1029/ 2007WR006545)

Lehning M, Grünewald T and Schirmer M (2011) Mountain snow distribution governed by an altitudinal gradient and terrain roughness. Geophys. Res. Lett., 38(19), L19504 (doi: 10.1029/ 2011GL048927)

Liston GE (2004) Representing subgrid snow cover heterogeneities in regional and global models. J. Climate, 17(6), 1381-1397 (doi:10.1175/1520-0442(2004)017<1381:RSSCHI>2.0.CO;2)

Luce CH, Tarboton DG and Cooley KR (1999) Sub-grid parameterization of snow distribution for an energy and mass balance snow cover model. Hydrol. Process., 13(12-13), 1921-1933 (doi: 10.1002/(SICl)1099-1085(199909)13:12/13<1921::AIDHYP867>3.0.CO;2-S)

Lundberg A, Granlund N and Gustafsson D (2010) Towards automated 'Ground truth' snow measurements - a review of operational and new measurement methods for Sweden, Norway, and Finland. Hydrol. Process., 24(14), 1955-1970 (doi: 10.1002/hyp.7658)

Lundquist JD and Dettinger MD (2005) How snowpack heterogeneity affects diurnal streamflow timing. Water Resour. Res., 41(5), W05007 (doi: 10.1029/2004WR003649)

MacQueen J (1967) Some methods for classification and analysis of multivariate observations. In Le Cam LM and Neyman J eds. 
Proceedings of the 5th Berkeley Symposium on Mathematical Statistics and Probability, Vol. 1. University of California Press, Berkeley, CA, 281-297

Marchand W-D and Killingtveit $\AA$ (2005) Statistical probability distribution of snow depth at the model sub-grid cell spatial scale. Hydrol. Process., 19(2), 355-369 (doi: 10.1002/hyp.5543)

Melvold K and Skaugen T (2013) Multiscale spatial variability of lidar-derived and modeled snow depth on Hardangervidda, Norway. Ann. Glaciol., 54(62 Pt 2), 273-281 (doi: 10.3189/ 2013AoG62A161)

Mott R, Schirmer M, Bavay M, Grünewald T and Lehning M (2010) Understanding snow-transport processes shaping the mountain snow-cover. Cryosphere, 4(4), 545-559 (doi: 10.5194/tc-4-5452010)

Mott R, Schirmer M and Lehning M (2011a) Scaling properties of wind and snow depth distribution in an Alpine catchment. J. Geophys. Res., 116(D6), D06106 (doi: 10.1029/ 2010JD014886)

Mott R and 6 others (2011b) Micrometeorological processes driving snow ablation in an Alpine catchment. Cryosphere, 5(4), 10831098 (doi: 10.5194/tc-5-1083-2011)

Nolin AW (2010) Recent advances in remote sensing of seasonal snow. J. Glaciol., 56(200), 1141-1150 (doi: 10.3189/ 002214311796406077)

Olea RA (1999) Geostatistics for engineers and earth scientists. Kluwer Academic, Boston

Pomeroy JW and 6 others (1998) An evaluation of snow accumulation and ablation processes for land surface modelling. Hydrol. Process., 12(15), 2339-2367 (doi: 10.1002/(SICl)10991085(199812)12:15<2339::AID-HYP800>3.0.CO;2-L)

Prokop A, Schirmer M, Rub M, Lehning M and Stocker M (2008) A comparison of measurement methods: terrestrial laser scanning, tachymetry and snow probing for the determination of the spatial snow-depth distribution on slopes. Ann. Glaciol., 49, 210-216 (doi: 10.3189/172756408787814726)

Rittger K, Painter TH and Dozier J (2013) Assessment of methods for mapping snow cover from MODIS. Adv. Water Resour., 51, 367-380 (doi: 10.1016/j.advwatres.2012.03.002)

Sailer R, Fromm R, Jörg P, Schaffhauser A and Adams M (2008) Ground based remote sensing of snow properties and avalanche simulation. In Proceedings of the International Conference on Studying, Modeling and Sense Making of Planet Earth, 1-6 June, 2008, Mytilene, Lesvos, Greece. http://www.geo.aegean.gr/ earth-conference2008/papers/papers-per-name.html\#Sailer\% 20Rudolf

Sailer R, Bollmann E, Hoinkes S, Rieg L, Spross M and Stötter J (2012) Quantification of geomorphodynamics in glaciated and recently deglaciated terrain based on airborne laser scanning data. Geogr. Ann. A, 94(1), 17-32 (doi: 10.1111/j.1468-0459. 2012.00456.x)

Schaffhauser A and 6 others (2008) Remote sensing based retrieval of snow cover properties. Cold Reg. Sci. Technol., 54(3), 164175 (doi: 10.1016/j.coldregions.2008.07.007)

Schirmer M and Lehning M (2011) Persistence in intra-annual snow depth distribution: 2. Fractal analysis of snow depth development. Water Resour. Res., 47(W9), W09517 (doi: 10.1029/ 2010WR009429)

Schirmer M, Wirz V, Clifton A and Lehning M (2011) Persistence in intra-annual snow depth distribution: 1. Measurements and topographic control. Water Resour. Res., 47(W9), W09516 (doi: 10.1029/2010WR009426)
Schöber J, Achleitner S, Kirnbauer R, Schöberl F and Schönlaub H (2010) Hydrological modelling of glacierized catchments focussing on the validation of simulated snow patterns: applications within the flood forecasting system of the Tyrolean river Inn. Adv. Geosci., 27, 99-109 (doi: 10.5194/adgeo-27-99-2010)

Schöber J and 6 others (in press) Snow cover characteristics in a glacierized catchment in the Tyrolean Alps: improved spatially distributed modelling by usage of Lidar data. J. Hydrol. (doi: 10.1016/j.jhydrol.2013.12.054)

Schweizer J, Kronholm K, Jamieson JB and Birkeland KW (2008) Review of spatial variability of snowpack properties and its importance for avalanche formation. Cold Reg. Sci. Technol., 51(2-3), 253-272 (doi: 10.1016/j.coldregions.2007.04.009)

Sevruk B (1986) Correction of precipitation measurements: Swiss experience. In Sevruk B ed. Precipitation Measurement. Proceedings of the ETH/IASH/WMO Workshop on the Correction of Precipitation Measurements, 1-3 April 1985, Zürich, Switzerland. (Zürcher Geographische Schriften 23) ETH Zürich, 187-196

Shook K and Gray DM (1996) Small-scale spatial structure of shallow snowcovers. Hydrol. Process., 10(10), 1283-1292 (doi: 10.1002/(SICI)1099-1085(199610)10:10<1283::AID-HYP460> 3.0. (O; $2-\mathrm{M})$

Sold L, Huss M, Hoelzle M, Andereggen H, Joerg PC and Zemp M (2013) Methodological approaches to infer end-of-winter snow distribution on alpine glaciers. J. Glaciol., 59(218), 1047-1059 (doi: 10.3189/2013JoG13J015)

Strasser U (2008) Modelling of the mountain snow cover in the Berchtesgaden National Park. (Forschungsbericht 55) Nationalpark Berchtesgaden, Berchtesgaden

Sturm M and Wagner AM (2010) Using repeated patterns in snow distribution modeling: an Arctic example. Water Resour. Res., 46(W12), W12549 (doi: 10.1029/2010WR009434)

Sun W, Xu G, Gong P and Liang S (2006) Fractal analysis of remotely sensed images: A review of methods and applications. Int. J. Remote Sens., 27(22), 4963-4990 (doi: 10.1080/ 01431160600676695)

Swenson SC and Lawrence DM (2012) A new fractional snowcovered area parameterization for the Community Land Model and its effect on the surface energy balance. J. Geophys. Res., 117(D21), D21107 (doi: 10.1029/2012JD018178)

Tappeiner U, Tappeiner G, Aschenwald J, Tasser E and Ostendorf B (2001) GIS-based modelling of spatial pattern of snow cover duration in an alpine area. Ecol. Model., 138(1-3), 265-275 (doi: 10.1016/S0304-3800(00)00407-5)

Trujillo E (2007) Topographic, meteorologic, and canopy controls on the scaling characteristics of the spatial distribution of snow depth fields. Water Resour. Res., 43(W7), W07409 (doi: 10.1029/2006WR005)

Webster R and Oliver MA (2007) Geostatistics for environmental scientists, 2nd edn. Wiley, Chichester

Wehr A and Lohr U (1999) Airborne laser scanning: an introduction and overview. ISPRS J. Photogramm. Remote Sens., 54(2), 68-82 (doi: 10.1016/S0924-2716(99)00011-8)

Winstral A and Marks D (2014) Long-term snow distribution observations in a mountain catchment: assessing variability, time stability, and the representativeness of an index site. Water Resour. Res., 50(1), 293-305 (doi: 10.1002/2012WR013038)

Xu T, Moore ID and Gallant JC (1993) Fractals, fractal dimensions and landscapes: a review. Geomorphology, 8(4), 245-262 (doi: 10.1016/0169-555X(93)90022-T) 